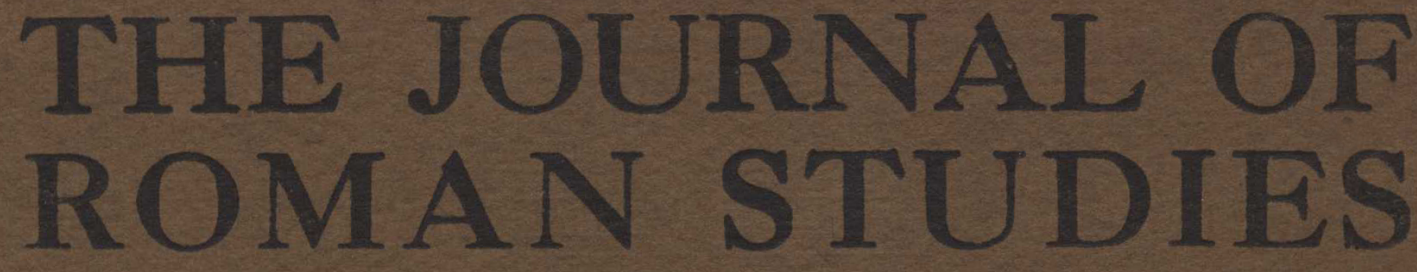

VOLUME XVIII. 1928

PART 1

\title{
CONTENTS
}

M. Holroyd. The Jugurthine war : was Marius or Metellus the real victor?

W. H. Buckler, W. M. Calder and C. W. M. Cox. Asia Minor, I924. V.-Monuments from the Upper Tembris Valley.

Ronald Syme. Rhine and Danube legions under Domitian.

E. B. Birley. A note on the title 'Gemina.'

S. N. Miller. Roman Xork: Excavations of 1926-1927.

\section{REVIEWS OF RECENT PUBLICATIONS}

Les institutions politiques romaines de la cité à l'état. Par Léon Homo.

Freedmen in the Early Roman Empire. By A. M. Duff.

L'administration civile de l'Êgypte byzantine. Par Germaine Rouillard.

The Invasion of Europe by the Barbarians. By the late J. B. Bury.

Lysippos. By Franklin P. Johnson.

Basilika, Yon Rudolf Schultze.

Les Celtes dans les arts mineurs greco-romains. Par Pierre Bienikowski.

Roman coins from the earliest times to the fall of the Western Empire. By Harold Mattingly.

The Roman Imperial coinage. Edited by H. Mattingly and E. A. Sydenham.

Forma Italiae: Regio I, Latium et Campania, Vols. I, II. Descripsit J. Lugli.

The Forum and the Palatine. By Christian Hülsen.
The Roman Campagna in Classical Times. By Thomas Ashby.

Preliminary report upon the excavations carried out in the Hippodrome of Constantinople in I927 on behalf of the British Academy.

Recherches à Salone. I.

Romans, Kelts and Saxons in Ancient Britain. By R. E, Zachrisson.

Royal Commission on Historical Monuments. An Inventory of the Historical Monuments in London. Vol. III., Roman London.

Histoire générale le Paris. Paris à l'époque galloromaine.

Harvard lectures on the Vergilian Age. By R. S. Conway.

Scriptores Historiae Augustae. Edidit E. Hohl.

A literary history of Rome from the origins to the close of the Augustan Age. By J. Wight Duff.

A literary history of Rome in the Silver Age. By J. Wight Duff.

\section{NOTICES}

La costituzione romana dai Gracchi a Giulio Cesare. Les antiquités romaines de la Rhénanie. Pas Da M. A. Levi.

Juden und Griechen im römischen Alessandreia. Von H. 1. Bell. C. Suetoni Tranquili Divus Vespasianus, Ed. A. W. The Border. By Brigadler-General W. Sitwell.
Braithwaite.

PUBLISHED BY THE SOCIETY FOR THE PROMOTION OF ROMAN STUDIES AT THE OFFICE OF THE SOGIETY 50 BEDFORD SQUARE W.C.1. TO BE OBTAINED THROUGH ALL BOOKSELLERS AND FROM THE SOGIETY. 


\title{
The society for the IDromotion of libellenic Studies
} Annual Subseription - ONE GUINEA. Entrance Foe - ONE GUINEA.

\author{
PRESIDRNT-PROFESSOR E. A. GARDNER, Litt.D.
}

OBJECTS.-The Society for the Promotion of Hellenic Studies was founded in 1879 for the following objects :-

I. - To advance the study of Greek language, literature, and art, and to illustrate the history of the Greek race in the ancient, Byzantine, and Neo-Hellenic periods, by the publication of memoirs and unedited documents or monuments in a Journal to be issued periodically.

II. - To collect drawings, facsimiles, transcripts, plans, and photogxaphs of Greek inscriptions, MSS., works of art, ancient sites and remains, and with this view to invite travellers to communicate to the Society notes or sketches of archaeological and topographical interest.

III. - To organise means by which members of the Society may have increased facilities for visiting ancient sites and pursuing archaeological researches in countries which, at any time, have been the sites of Hellenic civilisation.

Application for membership, or for information about the Society, should be addressed to the Secretary, at 50 Bedford Square, London, W.C.I.

The Journal of Hellenic Studies and other publications of the Society are issued by Messrs. Macmillan \& Co. Ltd, and can be purchased from any bookseller, the published price to non-members being $£^{2} 25$. net per volume or $€ 1$ rs. net each part. Members are entitled to receive a copy of the Jourtal on publication during their membership, and can purchase back volumes at the subscription rate of 2 rs. per annum.

Members also have the use of a well-equipped library at 50 Bedford Square, and of a large collection of lantern-slides illustrative of Greek and Roman Art and Antiquities, including sets of slides, complete with texts by the best authorities on the subjects selected.

\section{The Elassical Fssociation.}

The objects of the Classical Association are to promote the development and maintain the well-being of classical studies, and in particular (a) to impress upon public opinion the claim of such studies to an eminent place in the national scheme of education; (b) to improve the practice of classical teaching: (c) to encourage investigation and call attention to new discoveries; (d) to create opportunities for intercourie among lovers of classical learning.

Membership of the Association is open to men and women alike. The annual subscription is 5s. (life composition, $\ell_{4}$ ), and there is an entrance fee of 55 . (not charged to Libraries). Members receive a copy of the annual Proceedings of the Association and, on payment of $2 / 6$, of The Year's Work in Classical Studies (both post free). They may also obtain the Classical Review and Classical Quarterly at reduced prices, provided that the subscriptions be paid before January 3 ist in each year. Subscriptions sent in later than that date must be at the rates offered to the general public.

Inquiries and applications fox membership should be addressed to the Hon. Treasurer, H. F. Hose, M.A., Dulwich College, S.E.2I; or to either of the Hon. Secretaries, E. Norman Gardiner, D.I.itt., I, Linton Road, Oxford, and Miss E. C. Gedge, M.A., Crayford Rectory, Kent; or to the Hon. Secretary of any of the Local Branches-viz., E. D. T. Jenkins, M.A., University College, Aberystwyth; Miss M. E. Lees, M.A., University College, Bangor; C. W. Baty, M.A., 49 , Waterloo Road, Bedford; G. A. Auden, M.D., M.A. F.R.C.P., F.S.A., 42, Lordswood Road, Harborne, Birmingham; W. L. Cuttle, M.A., The University, Bristol: J. E. Scott, M.A., Caius College, Cambridge; L. J. D. Richardson, M.A., Fernshaw, Hilary Road, Llanishen, Cardiff: M. M. Gillies, Ph.D., The University, Hull; Miss Towne, County School for Girls, Beckenham, Kent; D. E. F. Binyon, The University, Leeds; Miss A. I. S. Smith, Girls' Grammar School, Bradford; R. B. Onians, Ph.D., 35, Mount Street, Liverpool ; Miss E. J. Vaughan, B.A., University College, W.C.r. F. H. Sandbach, B.A., The University, Manchester; B. Anderton, M.A., Public Library, Newcastle-on-Tyne: Professor F. S. Granger, University College, Nottingham; T. B. L. Webster, M.A. Ch. Ch. Oxford; Miss N. C. Jolliffe, The University, Reading; Mrs. Jackson, The Cottage, Cordwell Valley, Holmesfield, Nr. Sheffield; G. W. Dyson, B.A., University College, Southampton; F. Fletcher, M.A., University College, Exeter; Miss W. A. Odell, Brighton and Hove High School for Girls; H. Hill, M.A., University Coll., Cardiff. 


\section{THE JOURNAL OF ROMAN STUDIES}


All rights reserved. 


\section{THE JOURNAL OF ROMAN STUDIES}

\section{VOLUME XVIII}

PUBLISHED BY THE SOCIETY FOR THE PROMOTION OF ROMAN STUDIES AT THE OFFICE OF THE SOCIETY, 5O BEDFORD SQUARE, W.C. . LONDON 1928 
The printing of this part was completed on October 23, 1929. 


\section{CONTENTS.}

II. Houroyd The Jugurthine War : was Marius or Metellus the real rictor : PACT

II. H. Buckler, W. XI. Calder and C. W. M. Cox. Asia Minor, 1924: Y. .. 2 I

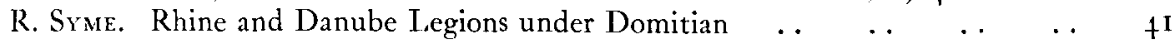

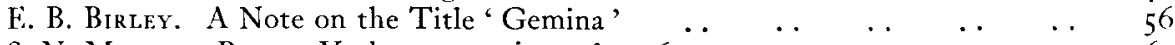

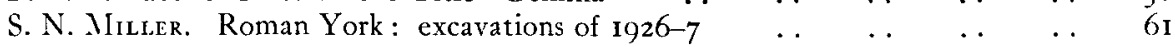

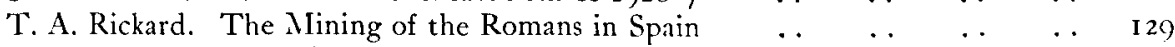

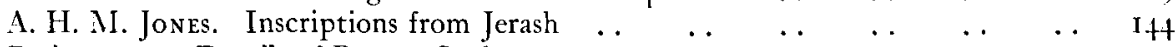

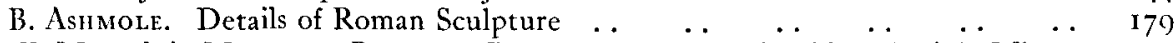

W. M. and A. Margaret Ramsay. Roman Garrisons and Soldiers in Asia Mlinor ISI

R. G. Collingwood and M. V. TAylor. Roman Britain in $1928 \ldots \ldots$. . 191

J. Tornbee. Note on a Roman Sarcophagus in the Campo Santo, Pisa .. . 2 I 5

$\begin{array}{llllllllll}\text { Reviews and Discussions } & \ldots & \ldots & \ldots & \ldots & \ldots & \ldots & \ldots & \ldots & 217\end{array}$

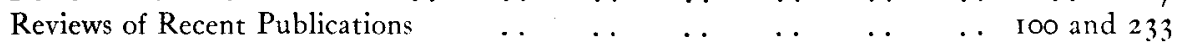

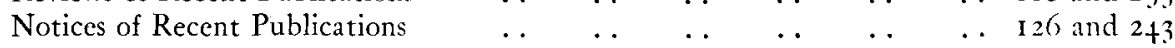

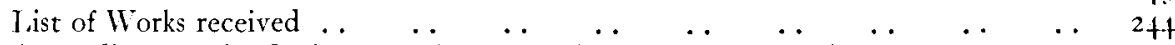

Procedings of the Society for the Promotion of Roman Studies, I028-o: open

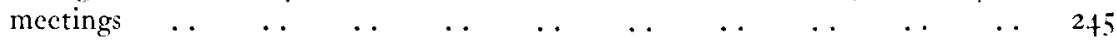

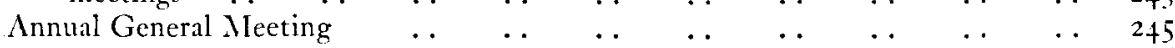

Report of the Council for the year ending 3ist December, I928 $\ldots \ldots \ldots$. $\ldots 246$

Income and Expenditure $\Lambda$ ccount for the year ending 3Ist December, 1928 . $\quad 249$

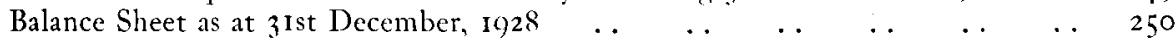

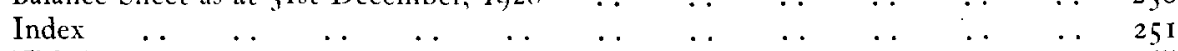

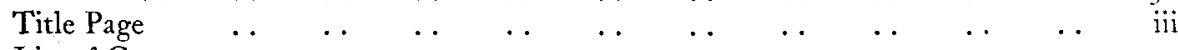

List $\begin{array}{llllllllllll} & \text { Contents . } & \ldots & \ldots & \ldots & \ldots & \ldots & \ldots & \ldots & \ldots & \ldots & \text { y }\end{array}$

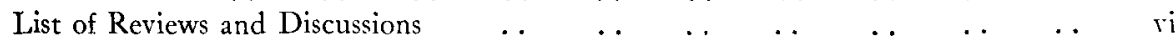

List of Reviews and Notices of Recent Publications $\quad \ldots \quad$. . $\quad \ldots \quad \ldots \quad \ldots \quad$ vi

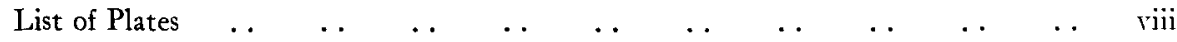

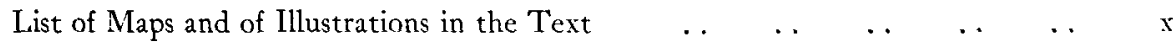

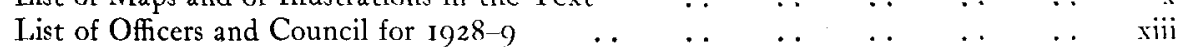

I.ist of Members, Student-Associates and Subscribing Tibrarics $\quad \ldots \quad \ldots \quad \ldots \quad \ldots \quad$ xiv 


\section{REVIEWS AND DISCUSSIONS.}

Geschichte des spätrömischen Reiches. Von Ernst Stein. Band I $\ldots \quad \ldots \quad 217$ Die Kaisergeschichte in Laktanz 'De mortibus persecutorum.' Von KarL Roller 226 Autour des Gracques : études critiques. Par Jérôme Carcopino .. $\quad \ldots \quad \ldots 228$

\section{REVIEWS AND NOTICES OF RECENT PUBLICATIONS.}

REVIEWS.

PAGE

Jes institutions politiques romaines de la cité à l'état. Par I.éon Hovo .. . . 100 Freedmen in the Early Roman Empire. By A. M. DufF . . $\quad \ldots \quad$. . $\quad \ldots \quad$ I00 L'administration civile de l'Egypte byzantine. Par Germaine Roulllard _. IO2 The Invasion of Europe by the Barbarians. By J. B. Bury $\quad \ldots \quad \ldots \quad \ldots \quad$. 103

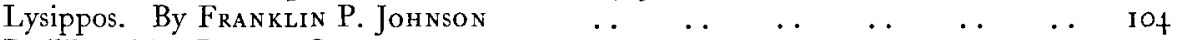

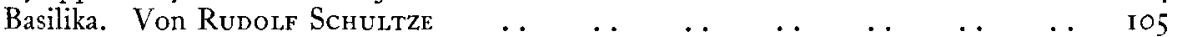
I.es celtes dans les arts mineurs greco-romains. Par Pierre Bieńnowski $\ldots$ io6 Roman Coins from the Earliest 'Times to the Fall of the Western Empire. By Harold Mattingly $\ldots$. The Roman Imperial Coinage. Edited by H. Mattingly and E. A. Sydenham.

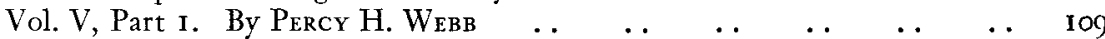
Forma Italiae: Regio I-Latium et Campania. Vol. I-Ager Pomptinus.

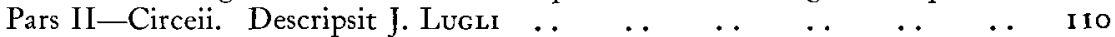
The Forum and the Palatine. By $C_{\text {Hristian Hulsen }} \quad \ldots \quad \ldots \quad \ldots \quad \ldots \quad \ldots \quad$ II I

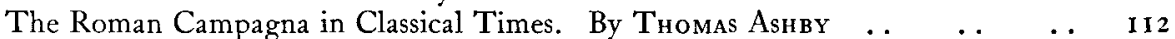
Preliminary Report upon the Excavations carried out in the Hippodrome of Constantinople in 1927 on behalf of the British Academy $\ldots \quad \ldots \quad \ldots \quad$ I13

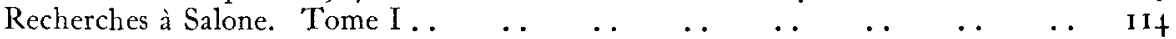
Romans, Kelts and Saxons in Ancient Britain. By R. E. Żachrisson $\quad \ldots \quad$. $\quad$ II7 Royal Commission on Historical Monuments. An Inventory of the Historical Monuments in London. Vol. III-Roman London .. $\quad \ldots \quad \ldots \quad \ldots \quad \ldots \quad$ II9 Histoire générale de Paris: Paris à l'époque gallo-romaine. Par F. G. de Pachtère IIq Harvard Lectures on the Vergilian Age. By R. S. Conway $\quad \ldots \quad$. . $\quad \ldots \quad$ I22

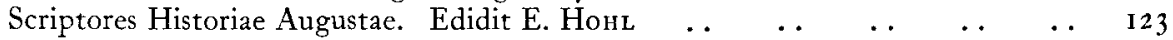
A Literary History of Rome from the Origins to the Close of the Augustan Age.

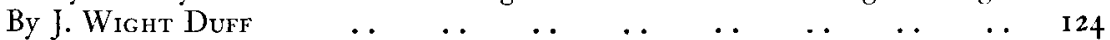
A Literary History of Rome in the Silver Age. By J. Wight Durf $\quad \begin{array}{llll}\ddot{0} & \cdots & \ldots & \text { I24 }\end{array}$

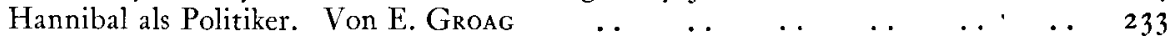

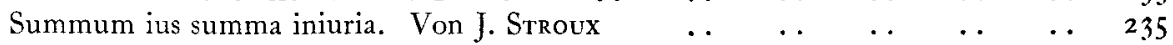

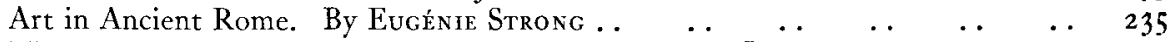

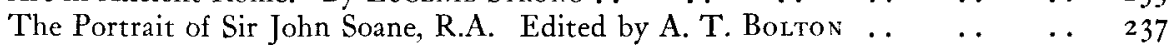
Histoire ancienne de l'Afrique du Nord. Par Stéphane Gsell, Tomes VII et VIII $23^{8}$ 


\section{REVIEWS AND DISCUSSIONS.}

Geschichte des spätrömischen Reiches. Von Ernst Stein. Band I $\ldots \quad \ldots \quad 217$ Die Kaisergeschichte in Laktanz 'De mortibus persecutorum.' Von KarL Roller 226 Autour des Gracques : études critiques. Par Jérôme Carcopino .. $\quad \ldots \quad \ldots 228$

\section{REVIEWS AND NOTICES OF RECENT PUBLICATIONS.}

REVIEWS.

PAGE

Jes institutions politiques romaines de la cité à l'état. Par I.éon Hovo .. . . 100 Freedmen in the Early Roman Empire. By A. M. DufF . . $\quad \ldots \quad$. . $\quad \ldots \quad$ I00 L'administration civile de l'Egypte byzantine. Par Germaine Roulllard _. IO2 The Invasion of Europe by the Barbarians. By J. B. Bury $\quad \ldots \quad \ldots \quad \ldots \quad$. 103

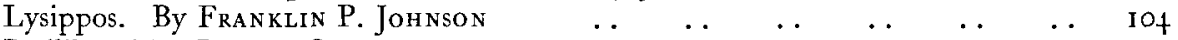

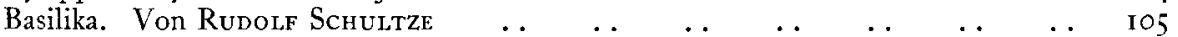
I.es celtes dans les arts mineurs greco-romains. Par Pierre Bieńnowski $\ldots$ io6 Roman Coins from the Earliest 'Times to the Fall of the Western Empire. By Harold Mattingly $\ldots$. The Roman Imperial Coinage. Edited by H. Mattingly and E. A. Sydenham.

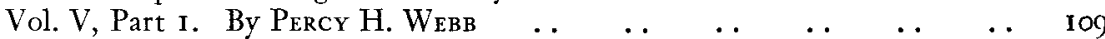
Forma Italiae: Regio I-Latium et Campania. Vol. I-Ager Pomptinus.

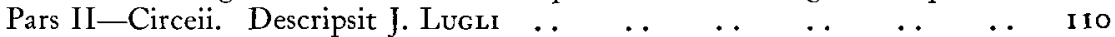
The Forum and the Palatine. By $C_{\text {Hristian Hulsen }} \quad \ldots \quad \ldots \quad \ldots \quad \ldots \quad \ldots \quad$ II I

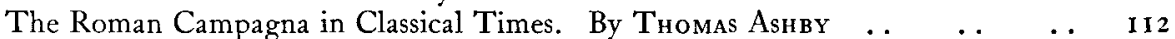
Preliminary Report upon the Excavations carried out in the Hippodrome of Constantinople in 1927 on behalf of the British Academy $\ldots \quad \ldots \quad \ldots \quad$ I13

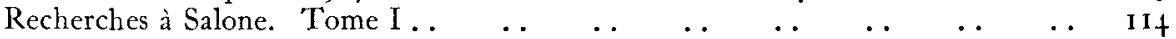
Romans, Kelts and Saxons in Ancient Britain. By R. E. Żachrisson $\quad \ldots \quad$. $\quad$ II7 Royal Commission on Historical Monuments. An Inventory of the Historical Monuments in London. Vol. III-Roman London .. $\quad \ldots \quad \ldots \quad \ldots \quad \ldots \quad$ II9 Histoire générale de Paris: Paris à l'époque gallo-romaine. Par F. G. de Pachtère IIq Harvard Lectures on the Vergilian Age. By R. S. Conway $\quad \ldots \quad$. . $\quad \ldots \quad$ I22

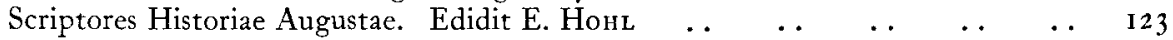
A Literary History of Rome from the Origins to the Close of the Augustan Age.

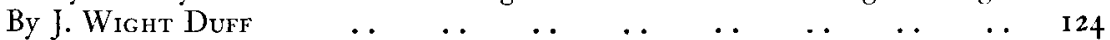
A Literary History of Rome in the Silver Age. By J. Wight Durf $\quad \begin{array}{llll}\ddot{0} & \cdots & \ldots & \text { I24 }\end{array}$

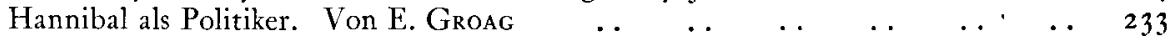

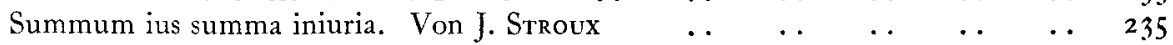

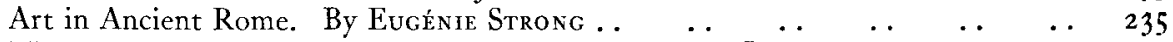

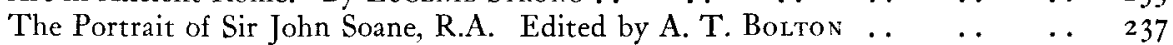
Histoire ancienne de l'Afrique du Nord. Par Stéphane Gsell, Tomes VII et VIII $23^{8}$ 


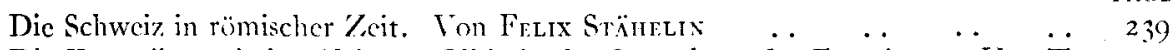

Die Keramik römischer $/$ cit aus Olbia in der Sammlung der Fremitage. Fon $\ddot{T}$.

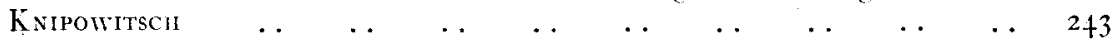

\section{xOTICES.}

La costituzione romana dai Gracchi a Giulio Cesare. Da M. A. IErr _ . . I 26

Juden und Griechen im römischen Alexandreia. Von H. I. Berl $\quad \ldots \quad$ I27

C. Suetoni Tranquilli Divus Vespasianus. Ed. A. W. Braithwaite $\quad \ldots \quad$. $\quad$ I27

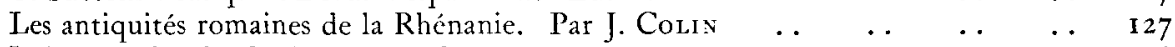

In Roman Scotland. By Jessie Mothersol.e $\ldots \begin{array}{llllllllll} & \ldots & \ldots & \ldots & \ldots & \ldots & \text {. } 28\end{array}$

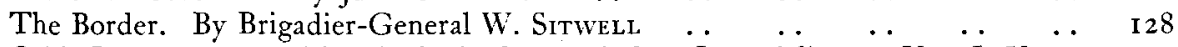

Orbis Romanus: zur Terminologie des römischen Imperialismus. Von J. Vogt 243

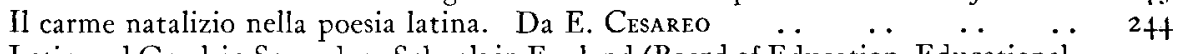

Latin and Greek in Secondary Schools in England (Board of Education, Educational

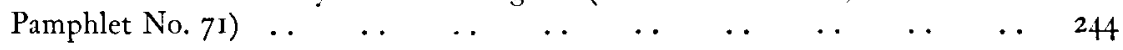




\section{LIST OF PL.ATES.}

Asia Minor, 1924. V. Monuments from the Upper Tembris Valley:

Plate I. Inscribed column at Chakyrsaz (no. 232); Inscribed block at Kurd Köi (no. 233); Inscribed bomos at Gedjek (no. 234); Inscribed bomos at Zemme (no. 238);

Platc If. Inscribed door-stone at Zemme (no. 239); Inscribed door-stone at Altyn Tash (no. 243); Inscribed door-stone in the mosque at Altyn Tash (no. 245).

Plate iI. Inscribed pediment at Altyn Tash (no. 247):

Decorated slab at Altyn Tash (no. 248b);

Inscribed panel at Chakyrsaz (no. 249);

Inscribed panel at Chakyrsaz (no. 250).

Roman York: Excavations of $1926-7$ :

Plate Iv. The east corner, looking west.

Plate v. I. Inner face of fortress-wall at east corner;

2. Earlier and later alignments of south-east wall of east corner-tower,

Plate vi. 1. The east corner, looking north-west ;

2. Cobbled rampart-walk outside north-west wall of east corner-tower.

Plate vil. I. Internal junction of nortl-west wall of east corner-tower with fortress-wall ;

2. Foundation of fortress-wall at junction with interval-tower;

3. Filling in east corner-tower ;

4. Inner face and foundation of fortress-wall in trench near west corner.

Plate vir. I. Piles under foundation of west corner-bastion;

2. Inner face and concrete foundation of fortress-wall in Section J ;

3. Inner face of fortress-wall in Section $\mathrm{K}$.

Plate Ix. I. Lower part of inner face of rampart-wall in Section G;

2. Outer face and foundation of back wall of interval-tower in Section $\mathrm{H}$;

3. Stratification behind interval-tower in Section $\mathrm{H}$;

4. Remains of Building VI in Section G;

5. Structural details of Room I of Building VI in Section G.

Plate $x$. Sections taken through the walls and the adjoining soil.

Plate XI. Outline-plan of the defences.

The Mining of the Romans in Spain.

Plate xir. I. Terra-cotta figurine of a slave working a screw-pump;

2. Part of a wooden screw-pump found near the Sotiel mine, Sprin.

Inscriptions from Jerash.

Plate xir. Inscribed stone block (no. 3);

Inscribed stone block (no. 6);

Inscribed altar (no. 8);

Inscribed stone slab (no. II).

Plate xiv. Squeeze of the Decree of the Sacred Synod of Dionysiac Artists (no. I4). 
Plate xw. Lnscription on the podium between the carea and the orchestra in the South Theatre (no. 13);

Inscribed fragment of a stone block (no. 15);

Inscribed fragment of an architrave-block (no. 19);

Inscribed console (no. 20);

Parts of the Nymphaeum-inscription (no. 22).

Platc xvi. Inscribed stone block (no. 27);

Inscribed architrave-block (no. 34);

Inscribed base of a cylindrical cippus (no. +0$)$;

Inscribed sarcophagus (no. 5I).

Details of Roman Sculpture.

Plate xvil. I, 2. Specimen details of the statue of Augustus from Prima Portil, (Vatican);

3, +. Details of the reliefs from the Hadrianeum (Palazzo dei Conservatori);

5, 6. Details of a bust of Commodus (Palazzo dei Conservatori).

Roman Britain in 1928.

Plate xvin. Caerleon: cutting through the NW. defences.

Plate xix. Caerleon: general view of one of the barrack-buildings.

Plate $\mathrm{xx}$. Colchester : interior of building in Holly 'Trees Field, looking sout'l.

Plate xxi. Colchester: interior of building in Holly Trees Field, looking north.

Plate xxir. Richborough: I. Bronze steel-yard weight.

2. Samian skillet.

Plate xxir. Colchester: Roman tombstone.

Note on a Roman Sarcophagus in the Campo Santo, Pisa.

Plate xxiv. Front of an early second century sarcophagus in the Campo Santo, Pisa.

Plate xxv. The ends of the same sarcophagus. 


\section{LIST OF MAPS AND ILLUSTRATIONS IN THE TEXT.}

The Jugurthine War :

PAGE

Map of NW. Africa : physical features $\ldots$. Map of Old Nrmidia and the Province of Africa $\quad \ldots \quad$.

Asia Minor, 1924. V. Monuments from the Upper Tembris Valley:

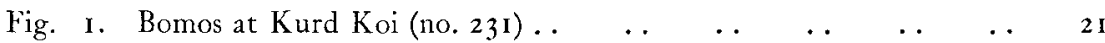

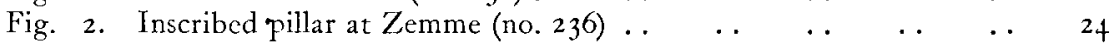

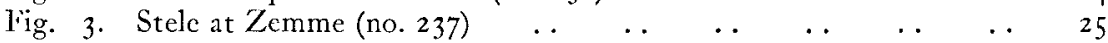

Fig. 4. Stele at Zemme (no. 240)

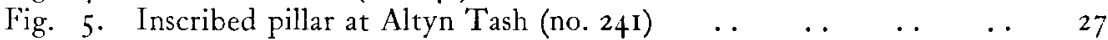

Fig. 6. Inscribed and decorated arch at Altyn Tash (no. 242) $\quad . . \quad \ldots \quad 28$

Fig. 7. Stele at Altyn Tash (no. 244) $\quad$.

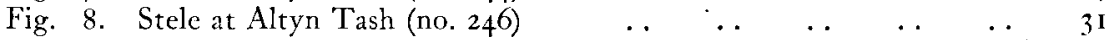

Fig. 9. Inscribed lintel at Altyn Tash (no. 248a) $\quad$.

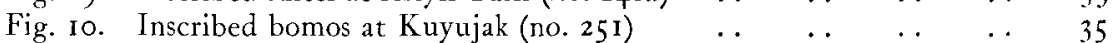

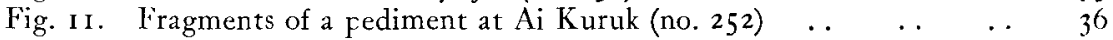

Fig. I2. Stele at Chukurler station (no. 253) $\quad$.

Fig. 13. Inscription on a slab at Chukurler station (no. 254) $\quad \ldots \quad \ldots 3^{8}$

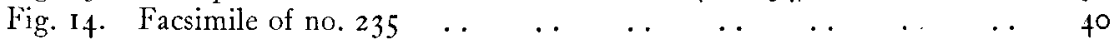

Roman York: Excavations of $1926-7$ :

Fig. 15. Sections across rampart-wall and tower at east corner $\quad \ldots \quad \ldots 663$

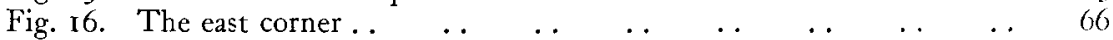

Fig. 17. Interval-tower $\left(\begin{array}{llllllll}\text { Site III) } & \ldots & \ldots & \ldots & \ldots & \ldots & \ldots & 69\end{array}\right.$

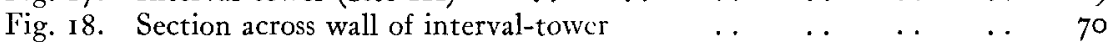

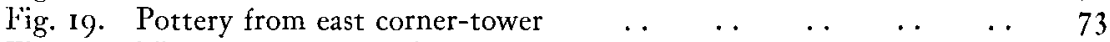

Fig. 20. The eastern part of the fortress $\quad \ldots \quad$.

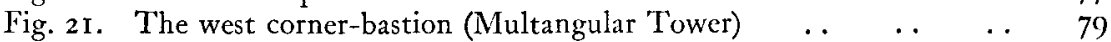

Fig. 22. Fragments of slip-coated beakers of $\mathrm{New}$ Forcst and latc-Cistor

Fig. 23. Fragments of coarse pottery from the ditcli opened in trench at $\ddot{\vec{F}}$ $\begin{array}{llllllllll}\text { (fig. } 2 \mathrm{I}) \quad \ldots & \ldots & \ldots & \ldots & \ldots & \ldots & \ldots & \ldots & 82\end{array}$

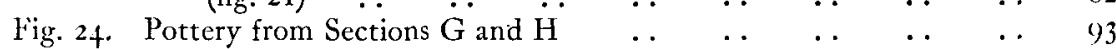

Fig. 25. Pottery from Site IX (plate xi) $\quad \ldots \begin{array}{llllll}\text { (p) } & \ldots & \ldots & \ldots & \ldots & 97\end{array}$

Inscriptions from Jerash :

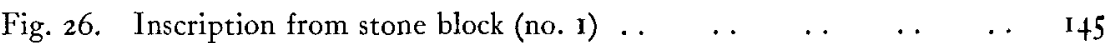

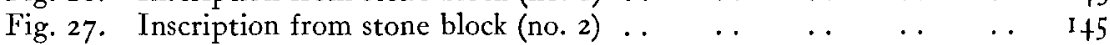

Fig. 28. Inscribed altar (no, 4) .

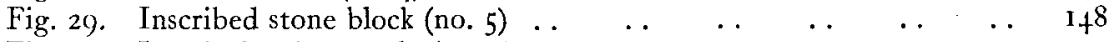

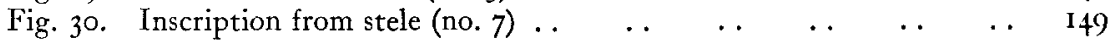

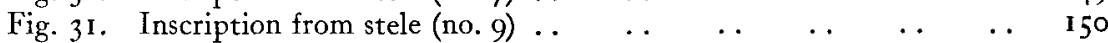

Fig. 32. Inscription from stone block (no. Io) $\quad \ldots \begin{array}{lllll} & \ldots & \ldots & \ldots & \text { I } 50\end{array}$

Fig. 33. Inscription found in the South Theatre (no. I2)

Fig. 34. The original form of no. 12 . .

Fig. 35. Stone basis bearing the Decree of the Sacred Synod of Dionysiac

$\begin{array}{llllllllll}\text { Artists } & \text {. } & \text {. } & \text {. } & \text {. } & \text {. } & \text {. } & \text {. } & \text {. } & \text { I54 }\end{array}$ 
Fig. 36. Inscription from fragmentary block (no. 15a) PACF

Fig. 36. Inscription from fragmentary block (no. 15a) $\quad \ldots \quad \ldots \quad \ldots \quad \ldots \quad$ i 56

Fig. 37. Inscription from the South Theatre (no. I6) $\quad \ldots \quad \ldots \quad \ldots \quad \ldots$ I57

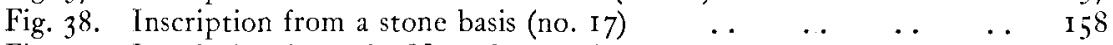

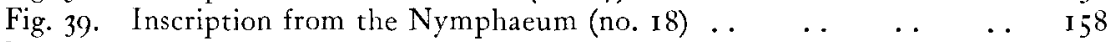

Fig. 40. Part of inscription from the architrave of the propylaea (no. 19) I59

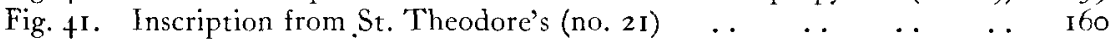

Fig. +2. Plan of the inscribed architrave of the Nymphaeum $\ldots . \quad \ldots \quad$ I6I

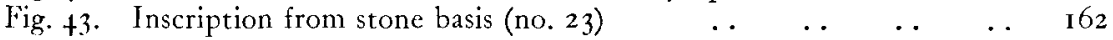

Fig. 44. Inscription from basis in the Wadi ed-Deir (no. 24) $\quad \ldots \quad \ldots \quad$ I63

Fig. 45. Inscription on block in front of the propylaea (no. 25) $\quad \ldots \quad \ldots \quad 163$

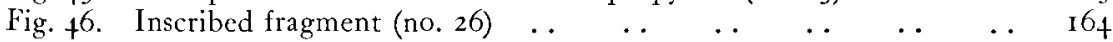

Fig. 47. Inscribed block in front of the propylaea (no. 28) $\quad \ldots \quad \ldots \quad \ldots \quad \ldots \quad$ I64

Fig. 48. Inscription from basis opposite the propylaea (no. 29) $\quad \ldots \quad \ldots \quad$ I65

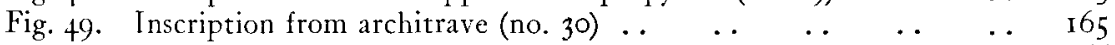

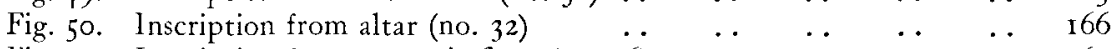

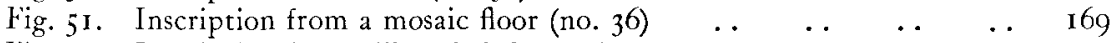

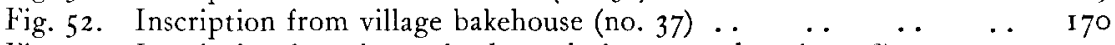

Iig. 53. Inscription from base of column before propylaea (no. $3^{8}$ ) $\quad \ldots \quad$ I7 I

Fig. 54. Inscription from cippus in the north baths (no. 39) A $\quad \ldots \quad$ I71

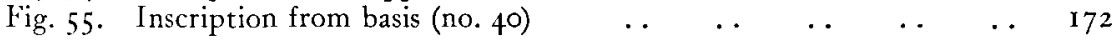

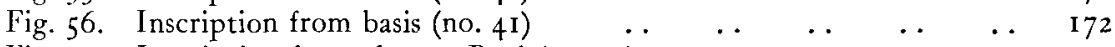

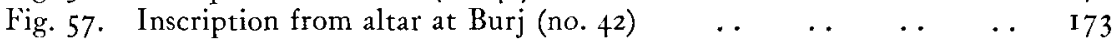

Fig. 58. Stone block from base of the baldachino of the altar in St. Theodore's

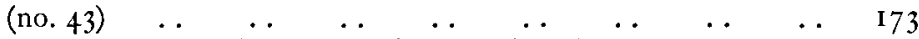

Fig. 59. Fragments from church opposite the propylaea (no. 44) $\ldots \quad$. 174

Fig. 6o. Inscription from the Nymphaeum (no. 47) $\ldots \ldots \ldots \ldots$. . $\quad \ldots \quad$ I75

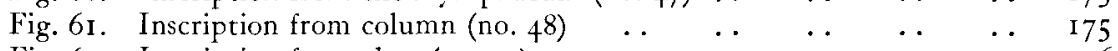

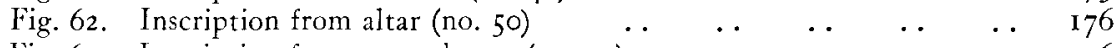

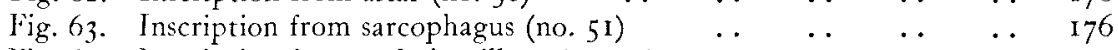

$\begin{array}{lllllll}\text { Fig. 64. Inscription from stele in village (no. 52) } & \ldots & \ldots & \ldots & \ldots & 177\end{array}$

Fig. 65. Inscription from house in village (no. 54) $\quad \ldots \quad \ldots \quad \ldots \quad \ldots \quad \ldots \quad$ I 77

Roman Britain in 1928.

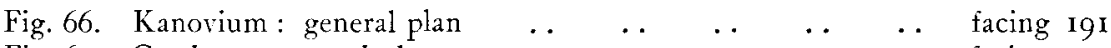

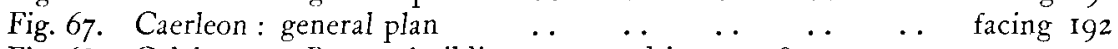

Fig. 68. Colchester: Roman building excavated in 1927-8 .. . 202

Fig. 69. Iondon: Mill-stone found at the corner of Princes Street and

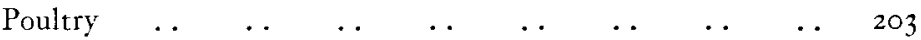

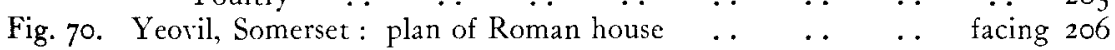

Fig. 7r. Caerleon : marble slab with inscription to Trajan .. .. .. 2I I 


\title{
SOCIETY FOR THE PROMOTION \\ OF ROMAN STUDIES.
}

\section{OFFICERS AND COUNCIL FOR 1928-1929.}

\author{
President: \\ PRINCIPAL H. STUART JONES, D.LITT. F.B.A.
}

\section{Vice-Presidents.}

PROF. F. E. ADCOCK, D.LITT. M.A. THOMAS ASHBY, M.A. F.B.A. D.LITT, F.S.A.

R. C. BOSANQUET, M.A. F.S.A.

SIR A. J. EVANS, D.LITT. F.R.S. F.S.A. F.B.A.

G. F. HILL, LL.D. LITT.D. F.B.A.

T. RICE HOLMES, D.LITT. LITT.D.

SIR FREDERIC KENYON, C.B.E. K.C.B. D.LITT. LITT.D. LL.D. F.B.A.

SIR G. MACDONALD, K.C.B. D.LITT. LL.D. F.B.A. J. W. M.ACLIAIL, LL.D. F.B.A.

L. C. PURSER, LITT.D.

SIR W. M. RAIISAY, D.LITT. D.C.L. LL.D. F.B.A. THE RIGHT HON. SIR J. RENAELL RODD, G.C.M.G. G.C.V.O. C.B.

A. H. SMITH, C.B. F.S.A.

\section{Ordinary Members of Couneil.}

Elected Jure, 1926.

PROF. J. G. C. ANDERSON, LL.D

PROF, B. ASHMOLE, M.A.

W. H. BUCKLER, M.A.

PROF. W. M. CALDER, M.A.

CHARLES HIGNETT, M.A.

M. HOLROYD, M.A.

H. C. OAKLEY, MA.

PROF. H. J. ROSE, M.A

\section{Elected June 1927.}

J. P. BUSHE-FOX, F.S.A.

R. G. COLLINGWOOD, M.A. F.S.A.

H. M. LAST, M.A.

Treasurer.

ROBERT HOLLAND-MARTIN, C.B., F.S.A.
H. MATTINGLY, M.A.

A. D. NOCK, M.A.

PROF. ORMEROD, M.A.

MISS J. TOYNEEF, M.A.

PROF. J. WIGHT-DUFF, M.A. IITT.D.

Elected June, 1929,

SIR JOHN BARRAN, BART.

N. H. BAYNES, M.A.

W. PAR KEER BREW!S, M.A. F.S.A.

C. W, M. COX, M.A

E. NORMAN GARDINER, D.LITT. ROBERT GARDNER, M.A.

T. DAVIES PRYCE, M.R.C.S. F.S.A.

G. MCN. RUSHFORTH, M.A. F.S.A:

\section{Auditor.}

C. T. EDGE, M.A., A.C.A.

\section{Editorial Committee.}

H. STUART JONES. SIR G. MACDONALD. F. E. ADCOCK. H. M. LAST.

\section{Keoper of Books and Lantern-slides.}

JOHN PENOYRE, C.B.E., M.A., so Bedfard Square, W.C.r.

\section{Secretary and Editor.}

MisS M. V. TAYLOR, M.A., F.S.A., Haverfeld Library, Ashmolean Museum, O siord. 


\title{
LIST OF MEMBERS.
}

To October Ist, I929.

\begin{abstract}
N.B.-It is requested that notice be given to the Secretary of any error, omission, change of address, resignation or death.
\end{abstract}

\section{HONORARY MEMBERS.}

R. Cagnat, Professeur au Collège de France, Secrétaire perpetuel de l'Académie des Inscriptions et Belles Lettres, 3 rue Ma arine, Paris, VJe.

Professore Gaetano De Sanctis, Via Santa Chiara 6r, Roma, Italy.

Professor Dr. Ernst Fabricius, Goetbestrasse 44, Freiburg-i-Dreisgau, Germany.

Professor Dr. Wilhelm Kubitschek, Picblergasse I, Wien, IX. Austria.

Professor M. Rostortzeff, Yale Station I9I6, Nev Maven, Conn., U.S.A.

\section{ORDINARY MEMBERS. \\ L indicates Life Compounder.}

L Abbott, Edwin, M.A. Jesus College, Cambridge.

Adams, P. H., F.R.I.B.A. 32 Cracen Street, $W . C .{ }^{2}$

Adcock, Prof. F. E., D.Litt., M.A. King's College, Camlridge.

Ainslie, Miss G. Sedber, Sherborne, Dorset.

Aitchison, W. de L. Killingwortb Hall, Nortbumberland.

Alford, Miss. 51 Gloucester Gardens, Bishop's Road, $W .2$

L Allen, P. S., M.A., D.Litt., F.B.A. Corpus Cbristi Colloge, Oxfor.t.

Alles, Dr. F. R. Britisb Hotel, Colombo, Ceylon.

Alton, E. H, M.A. 40 Trinity College, Dublin.

Anderson, Prof. J. G. C, LL.D. 25 Charlbury Road, Oxford.

Ariderson, R. H. 95 Alexandra Road, N.W.

Anderson, Prof. W. Blair, Litt.D. The University, Manchester.

Anderson, Prof. W. C. F, M.A. Hermits Hill, Burghfield Common, Reading.

Andrews, P. M., A.R.I.B.A. 9 Newcomen Street, S.E. ${ }^{1}$

Appleton, R. B. M.A. 187 Hills Road, Cambridge.

Armstrong, G. C. Levair, St. John's Road, Cosham, Hants.

L Ashby, Thomas, M.A., D.Litt., F.B.A., F.S.A. It Fia Vincenso'Bellini, Rone ( 36 , Italy.

Ashley, Miss A. M. Trinity Royd, Blackwall, Halifax, Torks.

Ashmole, Prof. B., M.A. Chesterfield, Meads, Eastbourne.

Atkinson, Prof. D., B.A. The Uniersity, Manchester.

Baddeley, St. Clair. Castle Hale, Painswick, Stroud, Glos.

Bagenal, Hope, A.R.I.B.A. 34 Bedford Square, W.C. ${ }^{1}$

Bagnani, Gibert. 4 Via S. Martino al Macao, Rome, Italy.

Bailey, C, M.A. Balliol College, Oxtord.

Bailey, W. O. Faircroft, Cobbam, Surrey.

Baillie Reynolds, P. K., B.A. The University College of Wales, Aberystwyth.

Baker, A. B. I.loyd, B.A. Devonsbire House, Batb Road, Cheltenbam.

Baldwin, The Rt. Hon. Stanley, M.A., M.P. Astlcy Hall, near Strurport. 
Balgarnie, W. H, M.A. The Leys Scbool, Cambridge.

Balsdon, J. P. V. D. Exeter College, Oxfurd.

Barber, E. A., M.A. Exetcr College, Oxford.

L Barlow, Miss A. E. F. Greenthorne, Edgworth, near Bolton.

Barnett, T. G. Rednal, Birmingham.

Barran, Sir John, Bart. S.roley Hall, Ripon.

Barrow, R. H. 24 Hilldown Road, S.W. ${ }^{16}$

Barton, Mrs. W: J., M.A. Ig Penny Street, Portsmouth

Basden, Miss M. F. 2i The Drive, Hove.

Batchelor, F, M.A. The Academy, Glasgcw.

Baty, C. W., M.A. 49 Waterloo Road, Bedford.

Baynes, N. H, M.A. Fttzwaiters, Northwood, Middlesex.

L Benecke, P. V. M, M.A. Magdalen College, Oxford.

L Benn, Mrs. Alfred. Il Ciliegio, Via del Palmerinn, Florence, Italy.

Bennett. S. A. Warreleigh, Budleigh Salterton, Devon.

Bensly, Prof. E, M.A. Uundle Cottage, Much Hadham, Herts

Bentinck, l'. Cavendish, F.S.A. 78 Harley Street, W. ${ }^{1}$

Benton, W. A. 30 Wretham Road, Handsworth, Birmingham.

Berry, Miss F. W. c/o Bank of Adelaile, i I Leadenball Street, E.C. ${ }^{3}$

$\mathbf{L}$ Berry, Sir James, Kt., F.R.C.S. F.S.A. Bramblebury, Dunsmore, nr. Wendover, Bucks. Bevan, E. R. Wray Lane House, Reigate.

L Billson, C. J., M.A. Weald House, Heathfield, E. Sussex.

$\mathbf{L}$ Birch, Mrs. J. E. Loraine House, Acre Lane, Wallington, Surrey.

Birley, E. B., B.A. Moorland, Didsbury, Manchester.

Bland, Miss E. D. 26 Luttrell Avenue, Putney, S.W $W^{15}$

Blegen, Mrs. C. W. 22 Regilla Street, Atbens, Greece.

Blomfield, Sir Reginald, M.A. R.A. F.S.A. 5 I Frognal, Hampstead, ${ } V . W{ }^{3}$

L Body, L. A., M.A. St. Chad's College, Durbam

L Bosanquet, R. C, M.A, F.S.A. Rock Moor, Alnteirk.

Bothamley, C. H., M.Sc. Resthaven, Yatton, sonerset.

Bowen, H. C. Caldy View, Tenby, S. Wales.

Bowra, C. M., M.A. Wadham College, Oxford.

Box, H., B.A. 23 University Road, Aberdeen.

Boyce, Sidney M., B.A. The Grammar School, Chorley.

Braunholtz, Prof. G. E. K. 22 Old Road, Headington, Oxon.

Brett, Mrs. A. B, M.A., F.R.N.S. 131 Maple Avenue, Fiusbing, N.Y., L'S.A.

Brewis, W. Parker. Glenbrae, Fesmond Park $W$ est, Nezocastle-on-Tj'ne.

Brice-Smith, R, M.A. Brightlands, Newnbam, Gloucestersbire.

Bridge, J. J. R. I Bloomfield Place, Bath.

Brigg, W. Anderton, M. A. LL.M. Kildwick Hall, nr. Keighley, 1'orks

Briggs, Miss M. G. Villa Mani, Oberwil, bei Basel, Switzerland.

Brighouse, T. K. Lower Wild Carr, Pateley Bridge, Harrogate.

Brooke, Rev. A. E, D.D. King's College, Cambridge.

Brown, A. Theodore. 25 Lord Strect, Liverpool.

Brown, Prof. G. Baldwin, M.A. The University, Edinburgh.

L Brown, James. Gala Hill, Galasbiels.

Brown, W. B. ro Corfton Road, Ealing, $W$.

Bruce-Clarke, Miss. Minley, Reigate.

Bruton, F. A., M.A., Litt.D. 27 Clcvedon Road, Weston-super-Mare.

Brydges, E. E. H, M.A. II Stone Buildings, Lincoln's Inn, W.C.?

Buck, Miss K. M., Holmzwod, 35 Princes Road, Buckburst Hill, E six.

Buckland, Prof. W. W, Litt.D. 9 Grange Terrace, Cambridge.

Buckler, W. H., M.A. I Bardzoll Rnad, Oxford.

L Bulwer, Miss. Dalling, Nr. Uckfield, Sussex.

L Bulwer, Miss Dora E. Dalling, Nr. Uckfeld, Sussex.

L Burdon, Rev. R. J. Parkburst House, Haslemere. 
Burnside, Rev. Canon W. F, M.A. St. Edmund's Scbonl, Canterbury.

Burrowes, Major P. W. Mont au Nord, Jerbourg, Guernsey.

L Bush, W. T. Columbia University, New York City: N.r., U.S.A.

Bushe-Fox, J. P., F.S.A., Benlomond House, Downshire Hill, Hampstead, N.W.

Butler, Prof. H. E, M.A. University College, London.

Butler, Harold. Heston Cottage, Heston, Middlesex.

L Buxton, Denis A. J. 43 Campden Hill Square, $W$.

Calder, Prof. W. M, M.A. The University, Mancbesier.

Callaghan, Rev. T. T. c/o Messrs. Bickers Es Sons, Charles Street, Haymarket, $W$.

Cameron, A., M.A. The Humanity Dept., The University, Edinburgb.

Cameron, Prof. D. J, M.A. Anderson House, Anderson Road, Colombo.

Capps, Prof. E. Princeton, New Jersey, U.S.A.

Carlisle, Mrs. M. Haverbrack House, Milnthorpe, Westmorland.

L Caroë, W. D, M.A. F.S.A. 3 Great College Street, Westminster, S.W. '

L Carthew, Miss. 6 Albert Place, Victoria Road, $W .8$

Cary, M, D.Iitt. 82 Tulbnt Roat, Highoate, $N{ }^{6}$

Caspersz, A., B.A. Polemead, Cranleigh, Guildford.

Chance, Arthur F. The Schools, Sbrewosbury.

Chapman, C. S., M.A. The Bede School for Boy:, Sunderland.

Charlesworth, M. P., M.A. St. Jobn's College, Cambridge.

Chitty, Rev. G. J, M.A. Eton College, Windsor.

Clark, Prof. A. C, M.A. Litt.D. F.B.A. Corpus Christi College, Oxtord

Clarke, J. Wilton Mansions, Glasgow, N.W.

Kitsun-Clarke, Col. Leeds.

L Clauson, Sir Charles. Hawkshead House, Hatfield.

Cleminson, F. J. 32 Harley Street, $W .1$

Clifton, E. W. V, M.A. II Meatur Bank, Chorltuneille, Mantiest r.

Cloke, F. A. Salisbury House, 5I Strand Street, Sandwick.

Coate, Miss Dora. The Higb School, Truro.

Cole, S. C, B.A. 32 Hampton Park, Redland, Bristol.

Colegate, A. I6 Princes Gardens, S.W. ${ }^{7}$

Coleman, R. H. F. New College, Harrogate.

Coleman, W. H., B.A. 22 Elgin Park, Redlands, Bristol.

Collingwood, R. G, M.A. F.S.A. Pembroke College, Oxford.

Collison, C. Lonsdale House, St. Bees, Cumberland.

Connall, Prof. B. M, M.A. 7 Claremont Drive, Headingley, Leeds.

Conway, Prof. R. S, M.A., Litt.D., F.B.A. Draethen, Didsbury, Manchester.

Cook, A. B, M.A. Queens' College, Cambridge.

Cooke, Rev. J. C, B.A. St. Bede's College. Manchester.

Cookson, C, M.A. Magdalen College, Oxford.

Corder, Philip, M.A. 4 Bootham Terrace, Tork.

Corley, F. E. Highfield, Witney, Oxon.

Cornford, Henley. 59 Ranelagh Gardens Mansions, S.W.6

Cornford, F. M, M.A. Conduit Head, Madingley Road, Cambiidge

Cotton, A. R., M.B.E., F.S.A. The White House, Epson.

Cox, C. W. M., M.A. New College, Oxjord.

Craig, J. D, M.A. The University, Sheffield.

Craster, H. H. E, M.A., D.Litt., F.S.A. All Souls College, Oxford.

Crees, Dr. J. H. K. The Catbedral School, Hereford.

Cripps, Mrs. Wilfred. Cripps Mead, Cirencester.

Crocker, A. J. 38 Cromwell Road, Feltbam, Middlesex.

Crossley, Miss V. G., M.A. Dozons Scbool, Seaford. 
Culley, Mrs. Willsugbby, Wildwood Road, Golders Green, N.W.11

L Cumont, Prof. F. I9 Corso d'Italia, Rome, Italy.

Cunnington, Mrs. M. E. 33 Long Street, Devizes.

Curle, James, LL.D., F.S.A. Priorwood, Melrose.

Dakyns, G. D, M.A. The White House, Iffley, Oxford.

Dalton, O. M, M.A., F.B.A, F.S.A. I2 Sydney Place, Bath.

Daniel, A. M. 2 Hampstead Hill Gardens, Rosslyn Hill, N.W. ${ }^{3}$

Danson, J. R., M.A., M.C. 74 Bidston Road, Birkenbead.

Dare, M. Paul. 6 Lincoln Street, Leicester.

Davison, J. A. Corpus Christi College, Oxford.

Dawkins, Prof. R. M, M.A. Plas Dulas, Llanddulas, Abergele, Denbighsbire.

Dean, Prof. L. R. Denison University, Obio, U.S.A.

Dennis, C. P. L., M.A., Ph.D. 39в Orcbard Road, Kingston-on-Thames, Surrey.

L Diubner, Prof. L. I ? Lugstrasse, Freiburg i/B, Germany.

L de Zulueta, Prof. F, M.A. D.C.L. New College, Oxtord.

Dickson, Mrs. George. Sesame Club, Grosvenor Street, $W .1$

Dobson, Miss K. H. I, Suffolk Square, Cheltenham.

Dodd, E. E, M.A. 20 Sheriff Lane, Eldwick, Bingley, Yorks.

Dodd, P. W, M.A. Fesus College, Oxford.

Drake, H. L, M.A. Pembroke College, Oxford.

Droop, Prof. J. P. 23 Ullet Road, Sefton Park, Liverpool.

Drummond, Kev. W. H. Highlands, De Warrenne Road, Lewes.

Duff, J. D., M.A. Strathaird, Cambridge.

Duff, Prof. J. Wight, M.A., Litt.D. Armstrong College, Newcastle-upon-Tyner

Dunning, Major J., D.S.O. 3 I Lombard Street, E.C.4

Duxfield, Miss M. I 3 Asb Street, Southport, Lancs.

Earl, G. C. 2914 McClure Street, Oakland, California, U.S.A,

Eastman, Mrs. Charlotte. Iowa City, Iowo I, U.S.A.

Ecob, P. E., M.A. Bedford Road Collegiate Institute, Saskatoon, Saskatchewan, Canada.

Edge, Cyril T, M.A., A.C.A. Vernon House, Sicilian Avernue, Soutbampton Rsw, W.C. '

Edmonds, J. M, M.A. Gryt-Howe Cottage, Storey's Way, Cambridge.

Egerton-Warburton, W., M.A. G.H.Q., British Army of the Rbine, c/o G.P.O., London, E.C.1

Elliot, Capt. W., R.F.A. 3 Montpellier Terrace, Sunderland.

Estelrich, J. Apart, 789, Barcelona, Spain.

L Evans, Sir A. J, M.A., D.Litt., LL.D., F.R.S., F.B.A., F.S.A. Youlbury, near Oxford.

Evans, Sir E. Vincent, K.C., C.H., LL.D., F.S.A., 64 Chancery Lane, W.C. ${ }^{2}$

Evans, Lady, M.A. 9 Kensington P'ark Gardens, $W .{ }^{11}$

Evans, Prof. D. Emrys. University College, Singleton Park, Swansea.

Ewing, James L, LL.D. Derreen, Murrayfield, Edinburgt.

Fair, Miss M. C. 2 Rigg Cottages, Eskdale, Cumberlanú.

Farquhar, James. Secondary Scbool, Leamington-on-Tyne.

Fell, Rev. R. A. L. I I 5 Wells Street, S.E. ${ }^{5}$

Fisher, Rev. G. F, M.A. The Hall, Repton, Derby.

L FitzHugh, Prof. Thomas. University of Virgimia, Chariottesville, Va. U.S.A.

L Fleming, Miss Halen J. Caerlee, Innerleitben, Peeblesbire.

Flemming, Percy, F.R.C.S. 89 North Gate, N.W. ${ }^{8}$

Fletcher, Sir Banister, F.R.I.B.A. I King's Bench Walk, E.C. ${ }^{4}$ 
xviii

Fletcher, Frank, M.A. 48 Polsloe Road, Exeter.

Fletcher, G. B. A. The University, Liverpool.

Flood, Rev. P. J., D.D. The Presbytery, Dabbeth, Tollerose, Glasgow.

Fordyce, C. J., M.A. Fesus College, Oxford.

Forsey, G. F. 6 Leigh Mansions, Oakmount Avenue, Soutbampton.

L Fowler, Rev. J. R. Curepipe, Mauritius.

Fox, Cyril, Ph.D., F.S.A. Four Elms, Heol Wen, Rhiwbina, Cardiff.

Francis, A. G, O.B.E., B.A., M.B., B.Sc., F.R.C.S. 20 Beacon Hill, N. ${ }^{7}$

Frank, Professor Tenney. Fobns Hopkins University, Baltimore, Maryland, U.S.A.

Franks, Percy, M.A. De Aston Grammar School, Market Rasen.

Frazer, Sir J. G., O.M., LL.D., D.Litt., Litt.D., D.C.L., F.B.A. Queen Anne's Mansions, St. Fames Park, S.W. ${ }^{1}$

Fremantle, Miss I. M. E, Huguenot University College, Wellington, Cape Province, S. Africa.

Freshfield, Douglas W, M.A. D.C.L. F.R.G.S. Wych Cross Place, Forest Row, Sussex.

Freshfield, E. H. Mint House, Upper Galton, Reigate.

Gair, Mrs. H. B. I 10 Goldburst Terrace, N.W.6

Gardiner, E. Norman, D.I.itt. I Linton Ruad, Oxford.

Gardner, Prof. E. A., M.A. Recess, Boyn Hill, Maidenbead.

Gardner, Prof. E. G, M.A. 5 Ruskin Close, Meadway, N.W.11

Gardner, Prof. Percy, LL.D., Litt.D., F.B.A., F.S.A. I 2 Canterbury Road, Oxlord.

Gardner, Eric, M.B., F.S.A. Portmore House, Weybridge.

Gardner, R, M.C. M.A. Emmanuel College, Cambridge.

Gardner, Willoughby, D.Sc., F.S.A., F.L.S. Deganwy, N. Waies.

L Genner, E. E., M.A. To Crick Road, Oxford.

Giles, A. F, M.A. 5 Palmerston Road, Edinburgh.

Giles, P, Litt.D. LL.D. The Lodge, Emmanuel College, Cambridge.

Gilson, J. P, M.A. British Museum, W.C. ${ }^{1}$

Giveen, R. L. Colet Court, Hammersmith Road, $W$.

L Gooch, G. P, M.A. South Villa, Campden Hill Road, W. 8

Gordon, Miss M. L. II 2 Victoria Road, Exmouth.

Gordon-Smith, C. S. 88 Coleberne Court, S.W. ${ }^{5}$

Graham, Miss W. M. Old Bury Hall, Ightham, Kent.

Gray, Rev. J. H, M.A. Queens' Coilege, Cambridge.

Greenup, G. F., B.A. I 4 Cambridge Park, Durdham Downs, Bristol.

Greenwood, J. A, LL.M. Funtington House, near Chichester.

Greenwood, L. H. G, M.A. Emmanuel Coillege, Cambridge.

Gregory, Miss A. M. 7 Lansdowne Road, Wolverbampton.

Grundy, Prof. W. W. ' Lerryn,' Rhiwbina, nr. Cardiff.

Gulbenkian, Nubar S. c/o C. S. Gulbenkian, Avenue d'léna, Paris, XVI.

Haddon, G. M. Mi. Glaisdale, Somerset Way, Iver, Bucks.

Hadow, Sir W. H, C.B.E. M.A. D.Mus. T be University, Sheffield.

Hall, Miss M. L, M.A. Baldock, Herts.

Hall, Miss W. L. 4 Homefield Road, Bromley, Kent.

Hallam, G. H., M.A. S. Antonio, Tivoli (Roma), Italy.

Hanby, Miss K. M. Boulevard Secondary School, Hull.

Hannah, Ian C., F.S.A. The Whim, Lamancha, Peeblessbire.

Hardie, R., S. Io Greycoat Gardens, S.W.1

Hare, W. L. 3 Gray's Inn Place, W.C. ${ }^{1}$

L Harrison, E, M.A. Trinity College, Cambridge.

Hart, Percival. Grove Lodge, Highgate, $N$. 
Hastings, G. I7 Welbury Drive, Bradford.

Hawkes, Christopher, B.A. British Museum, W.C.:

Heath, C. H, M.A. 224 Hagley Road, Birmingham.

Hedley, W. Percy. Gresham House, Corbridge-on-Tyne.

L Heitland. W. E, M.A. Carmefield, Wordsworth Grove, Cambridge.

Hemp, Wilfrid J, F.S.A. Minshull, High Wycombe.

Henderson, Thomas. Educational Institute of Scotland, 47 Moray Place, Edinburgh.

Henry, Prof. R. M, M.A. Queen's University, Belfast.

Herbert, Rev. George. 6i Preston Rnad, Brighton.

Hignett, Charles, M.A. Hertford College, Oxford.

Hill, Mrs. B. H. 22 Regilla Street, Athens, Greece.

Hill, G. F, M.A, LL.D., Litt.D., F.B.A. British Museum, W.C. ${ }^{1}$

Hill, Miss M. V, M.A. Uplands Scbool, Arcbery Road, St. Leonards-on-Sea.

Hinks, Roger. British Museum, London, W.C. ${ }^{1}$

Hiorns, F. R, F.R.I.B.A. I88a, Adelaide Road, St. Fobn's Wood, London, N.W. ${ }^{3}$

Hirst, Prof. G. M. Barnard College, Columbia University, New York City, U.S.A.

Hirtzel, Miss Ruth. 47 Palace Court, $W .^{2}$

Hodge, Harold, M.A. 9 Higbbury Place, $N .^{5}$

L Hodgkin, R. H, M.A. 20 Bradmore Road, Oxford.

Hodgkinson, H. R. The Titret House, Hampton Lovett, Droitwich.

Hogan, Rev. W. K. P. 55 Ricbmond Road, S.W. ${ }^{20}$

Holden, Miss. 54 Piazza di Spagna, Rome, Italy.

Holland Martin, R., C.B., F.S.A. 46 Thurloc Square, S.W. ${ }^{7}$

Holmes, T. Rice, D.Litt., Litt.D., F.B.A. I Akeburst Street, Roebampton, S.W.

L Holroyd, Michael, M.A. Brasenose College, Oxford.

Hollis, Rev. A. M. Hertford College, Oxford.

Home, Major Gordon. I King's Benct Walk, E.C. ${ }^{4}$

Hopkins, G. B. I, M.A. Orley Farm School, Harrow.

Hopkinson, Rev. Canon J. H., M.A. The Abbey, Carlisle.

Horn, Theodore, M.A. The Grammar Scbool, Stockport.

Jornsby, W. Saltburn-by-tbe-Sea.

L Hose, H. F. Dulwich College, S.E. ${ }^{21}$

Hoskyns, Frances, Lady. 39 Sloane Gardens, S.W.1

Hotson, J. E. B. c/0 Messrs. Grindlay छึ Co, P.O., Box 93, Bombay, India.

Housman, Prof. A. E., M.A. 'Trinity College, Cambridge.

L Howard, E. C. Hotel Beau-Séjour, Mustapha, Algiers.

Hulbert, H. L. P, M.D. Villa Feannette, Grasse, A.M. France.

Hulbert-Powell, Rev. C. Lacy. Burrell's Field, Cambridge.

Hunt, James. Rydal School, Colwyn Bay.

Hunter Blair, C. H, M.A., F.S.A. 57 Higbbury, Newcastle-upon-Tyne.

Hurst, W. T., M.A. 40 Chapel Street, Hyde, Chesbire.

L Hyde, J. H. 67 Boulevard Lannes, Paris, France.

Irons, Miss C. M., M.A. Aynhoe, Asbleigh Road, Horsbam, Sussex.

Jarrett, E. A. Architectural Association, 34 Bedford Square, W.C. ${ }^{\mathbf{I}}$

James, Rev. J. W, B.D. Portskewett, Mon.

Jardine, Miss Lindsay. 26 Murrayfield Road, Edinburgh.

Jelf, Charles R. Trapstile, Lustleigh, Devon.

Jelf, E. A. St. Mary's Cottage, Waxwell Lane, Pinner.

Jenkin, Miss I. A. Wynberg, Chestnut Avenue, Soutbborough, Tunbridge Wells.

L Jex-Blake, Miss K. + Airlie Gardens, Campden Hill Road, W. ${ }^{8}$

Johnson, Miss H. T. Ellesmere Lodge, The Park, Cheltenham.

Johnson, Miss Lorna A. Woodleigh, Altrincham. 
Jolliffe, Prof. R. O. Queen's University, Kingston, Ontario.

Jones, H. L, M.A. Willaston School, Nantwicb.

Jones, Principal H. Stuart, D.Litt. F.B.A. University College of Wales, Aberystwyth.

Jones, Surgeon Captain K. H., R.N., M.B., F.Z.S. The Manor House, St. Stephen's, Canterbury.

L Jones, Ronald P. I 3 Hornton Street, S.W. ${ }^{8}$

Judson, William. Dean Close School, Cbeltentam.

Keiller, A. 4 Cbarles Street, Berkeley Square, $W .{ }^{1}$

Kelland, G. T.. B.A. 5 Carlingford Road, Hampstcad, N.W. ${ }^{3}$

Kendall, Miss O. P. University College, Gower Street, W.C. ${ }^{1}$

Kenyon, Sir Frederic, G.B.E., K.C.B., D.Litt., Litt.D., LL.D.,F.B.A. Britisb Museum, W.C. ${ }^{1}$

Kerr, G. W. 7 Walsingham Avenue, West Didsbury, Manckester.

Kirk, J. L, B.A., M.B., B.Sc. Houndgate, Pickiring, Yorks.

Klein, Walter G, F.S A. 7 Eldon Road, $N . W^{3}{ }^{3}$

Knapton, Rev. A. J. The Vicarage, Clee St. Margaret, Craven Arms, Shropshire.

Knight, W. F. J. Bloxham School, nr. Banbury, Oxford.

Knowles, W. H, F.S.A., F.R.I.B.A. Well Close, Lansdown Parade, Chelenham.

Knox, Rev. W. L. The Oratory House, Lady Margaret Road, Cambridge.

Langford, F. C. G., M.A. 35 Alley Park, Dulwiich, S.E. ${ }^{21}$

Last, H. M, M.A. St. Fobn's College, Oxford.

L Laurand, Dr. L. 37 Boulevard de Tours, Laval (Mayenne), France.

Laurie, G. E. Roval Academical Institute, Belfast.

Laver, P. G., F.R.C.S., F.S.A. Broomfield, Ardleigh, Essex.

Lawrence, Sir A. 49 Marsham Street, S.W. ${ }^{1}$

Lawson, P. H., F.S.A. 2 Pepper Street, Chester.

Lee, Miss J. E. Horsley House, Tilford, Farnhant.

Leeper, Alexander, LL.D. St. Audoen's, Kensington Road, S. Yarra, Melbourne, Australia.

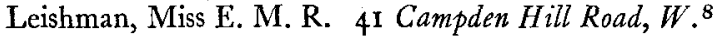

Letts, M. H. I. Io Bartlett's Buildings, Holborn Circus, E.C. ${ }^{4}$

Lewer, H. W, F.S.A. Priors, Loughton, Essex.

Lewis, Miss A. K. Brighton and Hove High School, Brighton.

L Lewis, J. Spedan clo Peter Fones, Ltd., Sloane Square, S.W. ${ }^{1}$

Lewis, Miss M. E. 6 Hillside, S.W. ${ }^{19}$

Linaker, R. Hyde, F.S.A. Rock Co:tage, Frodsbam.

Lindley, Miss. 74 Shooter's Hill Road, Blackheath, S.E. ${ }^{3}$

Livett, Rev. Canon G. M, F.S.A. Belmont, Wray Park Road, Reigate, Surrey.

Lloyd, Prof. J. E, M.A., D.Litt., F.S.A. Gwaen Deg, Bangor.

L Loeb, James. Hocbried, Murnau/Staffelsee, Bavaria.

Longbotham, G. F. 378 Linthorpe Road, Middlesbrough.

Longden, R. P., M.A. Cbrist Cburch, Oxford.

Low, D. M., M.A. Kelvinside Academy, Glasgozu.

Low, Miss Janet I. Blebo, Cupar, Fife.

Lowndes, Miss. clo Mr. Fames Bain, If King William Strest. Strand,W.C."

Lowther, A. W. G. The Old Quarry, Asbtead, Surrey.

McCulloch, Miss J. G., M.A. 2 Westbourne Terrace, Ibrox, Giss grwo.

L Macdonald, Sir George, K.C.B., D.Litt., LL.D., F.B.A. 17 Learmonth Gardens, Edinburgb.

Macdonald, Mrs. J. G. 3 Hope Street, St. Andrews, Scotland. 
L Macdonald, Miss L, M.A. 47 Seymour Street, Portman Square, $W .^{1}$

McDonell, H. C. M, M.A. Twvford Scbool, Winchester.

Macdonell, The Hon. Sir P. J. Supreme Court, Trinidad.

McElderry, Prof. R. Knox. Glenside, Sans Souci Park, Belfast.

McEvoy, Rev. C. 'Alesia,' Parkside Drive, Watford, Herts.

MacGregor, Rev. W, M.A., F.S.A. Boleball Manor House, Tamworth.

McIntyre, James. West View, Bishop Auckland.

McLellan, R. D. 90 Stanstead Road, Hertford.

Mackail, J. W, M.A., LL.D., F.B.A. 6 Pembroke Gardens, $W$.

L Mackey, Rev. Father Peter Paul, O.P. Collegio Angelico, I 5 Via San Vitale, Rome, Italy.

L Macmillan, Sir Frederick. 22 Devonshire Place, $W .{ }^{1}$

Macmillan, George A, D.Litt. 27 Queen's Gate Gardens, S.W.1

Macmillan, W. E. F. ${ }_{42}$ Cnslow Square. S. $W .{ }^{7}$

McMurtrie, Miss B. S. B. Craigrowan, Kilmacolm, Renfrewshire.

McNabb, Miss E. R. 23 India Strect, Glasgcw.

Magic, Prof. David. Ior Librarv Place, Princeton, New fersey, U.S.A.

Magoffin, Prof. R. V. D. New York University, University Heights, New York City, U.S.A.

Magrath, Rev. J. R, D.D. Provost's Lodgings, Queen's College, Oxford.

Makin, Miss Ena, M.A.

Manion, Rev. B., M.A. Cotton College, North Staffs.

L Mardon, A., M.A. The Rice Institute, Houston, Texas, U.S.A.

Marks, Geoffrey, C.B.E. Union Club, Io Carlton House Terrace, S.W. ${ }^{1}$

Marriage, Miss E. G. 62 Pont Street, S.W. ${ }^{1}$.

Marshall, Miss A. M. C. 3 Roedean Scbool, Brighton.

Marshall, D. W. H., M.A., I.L.B., B.Litt. University of Manituba, Winnipeg, Cunada.

Marston, Sir Charles, J.P. Afcot, Compton, Wolverbampton.

Martin, Miss A. P., M.A. 24 Murray House, Vaudon Street, S.W.1.

Martin, Alan R. 18 Kidbrook Park Road, S.E. ${ }^{3}$

Matheson, P. E., M.A. 3 Brookside, Headington, Oxford.

Mattingly, H, M.A. British Musenm, W.C. ${ }^{1}$

Maufe, F. B. I5 Hanover House, Regent's Park, $N . . W^{8}$

May, Thomas, M.A., F.S.A., F.S.A.Scot., F.E.T. Loxley Lodge, Loxley Road, Stratfordon-toon.

Meade, The Hon. Mrs. Edward. Guilsborough, Northampton.

Meiggs, R., M.A. Keble College, Oxford.

Michie, Prof. J. I, M.A. The University of Queensland, Brisbane, Austraiia.

Mildmay, Dr. E. St. John. Via Telesio 19, Milan.

Miles, Sir J. C, M.A. Merton College, Oxford.

Miller, S. N, M A. 13 Doune Terrace, Kelvinside N, Glasgow.

Millington, Miss M. V. 30 Peak Hill, Sydenbam, S.E. ${ }^{26}$

Mills, Miss Dorothy. The Brearley Schools, 6o East 6I st Strebt, New York, U.S.A.

Mills, T. R. University College, Dundee.

Milne, J. G., M.A., D.Litt, 20 Bardwell Road, Oxford.

Minns, Prof. E. H, Litt.D. Pembroke College, Cambridge.

Mond, Mrs. Angela. 22 Hyde Park Square, $W .{ }^{2}$

Montague, Lt.-Col. L. A. D., J.P., F.R.N.S. Penton, Crediton, N. Devon.

Moon, Miss E. M. ${ }_{3}$ Oakwood Court, Melbury Road, Kensington, $W .{ }^{4}$

Morcom, Col. Reginald K. The Clockbouse, Bromsgrove.

Morris, W. J, B.A. 23 Birchgrove Street, Porth, Rbondda.

Mothersole, Miss Jessie. Pilgrim's Peace House, Hampstead, N.W. ${ }^{3}$

Mozley, J. H., M.A. Kentons, Haslemere, Surrey.

Muirhead, A. M. 83 The Limes Avenue, N. Southgate, N. ${ }^{11}$

Muirhead, J. Spencer, LL.B., D.S.O., M.C. 205 St. Vincent Street, Glasgyro.

Munro, J. A. R, M.A. Lincoln College, Oxford.

Murray, Prof. G. G. A., D.Litt., LL.D., F.B.A. Boar's Hill, Oxford. 
L Myres, Prof. J. L, M.A., D.Litt., F.S.A. The Copse, Hinksey Hill, Oxford. L Myres, J. N. L., B.A. Christ Church, Oxford.

Nairn, Rev. J. A. Stubbings Vicarage, Maidenbead.

Nairne, Prof., D.D. Fesus College, Cambridge.

Nash, A. B. 36 Priory Road, Hornsey, $N{ }^{8}$

Nash-Williams, A. H.

Nash-Williams, V. E. The National Museum of Wales, Cardiff.

Newbold, W., O.B.E., H.M.I. clo Board of Education, Whiteball, S.W. ${ }^{1}$

Nisbet, R. G, M.A. 20 Ann Strret, Hillhead, Glargow.

Nock, A. D., M A Clare College, Cambridge.

Norman, Philip, LL.D., F.S.A. 45 Evelyn Gardens, S.W. ${ }^{7}$

Norris, Miss M. E. County High School for Girls, Churcb Hill, Walt ham, t, w, K.?

Norwood, Prof. G. University College, Toronto, 5 Canada.

Oakeshott, W. F. 54 Prince of Wales Mansions, Battersea, S.W. ${ }^{11}$

Oakley, H.C., M.A. 22 Ouseley Road, Balham, S.W.12

Ogle, Christopher. Browne's Lodge, Reigate.

Oldfield, Rev. W. J, D.D. Preb. of Lincoln, White Lodge, Abingdon.

Oliphant, Prof. S. G, Ph.D. 520 Stewart Av'nue, Grove City, Pennsvlvania, L'S A

Oliver, J. R., M.D. The Latrobe Apartments, Read and Charles Streets, Baltimore, U.S A.

Ormerod, Prof. H. A., M.C., M.A. 25 a Falkner Square, Liverpool.

Oswald, Felix, D.Sc., F.G.S., F.S.A. H.M. Probate Registrv, Nuttinglam.

Owen, A. S, M.A. Keble College, Oxford.

Owen, E. Bishop's University, Lennsxille, Quebec, Canada.

Owen, Prof. L. V. D. University College, Nottingtam.

Owen-Mackenzie, Lady, 6 Chesham Street, S.W. ${ }^{1}$

Pag=, T. E, Litt.D. Charterbouse, Godalming.

Palmer, A. E. Penryn, Temple Road, Stcwmarket.

Pantin, W. E. P., M.A. I7 Dewburst Road, West Kensington, $W .{ }^{14}$

Parish, A. Brockbolt, Otford, nr. Sevenoaks, Kent.

Parker, H. M. D, M.A. Magdalen College, Oxford.

Parker, Colonel J. W. R, C.B., D.L., F.S.A. Browsholme Hall, Clitheroc.

Parker, Dr. W. Rushton. Royal Institution, Albemarle Street, W. ${ }^{1}$

Passmore, A. D. Callar House, Wanborough, Wilts.

Paterson, Prof. A. C. Auckland University College, Auckland, New 7ealand.

Payne, Major A. A. Laporte. 47 Eton Court, Eton Avenue, $N . W{ }^{3}$

Pearce, J. W. E, M.A. 10 Cromwell Place, S.W. ${ }^{\top}$.

Pearson, Prof. A. C, Litt.D. Trinity College, Cambridge.

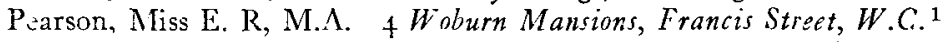

Pease, Mrs. Nether Grange, Alnmo:th.

Penoyre, John, C.B.E. M.A. 8 King's Bench Walk, Inner Temple, E.C. ${ }^{4}$

Penrose, Dame Emily, M.A., D.C.L. I4a Belsize Park Cardens, N.W. ${ }^{3}$

L Perram, Charles, M.D. Norland Court, 82 Gloucester Place, Portmatn Squate, $W .{ }^{1}$

Perry, F. T. Beecb Close, Car Colston, Notts.

Petch, J. A, M.A. The University, Manchester.

Pickard-Cambridge, Prof. A. W, M.A. The University, Edinburgh.

Pickstone, Miss J. Nortb Middlesex School for Girls, Enfield Chase, Middlesex.

Pierce, S. R. 39 St. James' Street, Bedford Row, W.C. ${ }^{1}$

L Piatnauer, Maurice, M.A. Brasenose College, Oxford.

L Plunkett, Count G. N., T.D. 40 Elgin Road, Dublin. 
Pccock, L. G. 26 Stanbope Road, Highgate, N. 6

Pollock, The Rt. Hon. Sir F., Bart., M.A., LL.D., D.C.L., F.B.A., F.S.A. 2 I Hyde Park Place, $W$. $^{2}$

L Pope, G. H, M.A., B.C.L. 60 Banbury Road, Oxford.

L Pope, Rev. J. O'Fallon, S.J. Manresa House, Roebampton, S.W. ${ }^{15}$

Porter, W. H. Lebenagb House, Cork.

Pratt, E. A. 4 Adelphi Terrace, W.C. ${ }^{2}$

Pratt, F. J. Tidd. 22 Balderton Gat; Newark.

Prescott, H. M. I 37 Higb Lever Road, $W .{ }^{10}$

Preston, A. W. Bishop's College, Lennoxville, Quebec, Canada.

L Preston, Colonel J. E. c/o Grindlay E Co., 54 Parliament Street, S.W. ${ }^{1}$ Price, Stanley, M.A. Glorishears, Rigtonbill Estate, East Keswick, Leeds. Prosser, W. B. Ardenlee, Maidstone.

Pryce, T. Davies, M.R.C.S, F.S.A. Bramber, Fletcber Road, Horsell, Surrey. Purser, Louis C., D.I.itt., Litt.D., F.B.A. $8 \mathrm{Waterloo} \mathrm{Rucd,} \mathrm{Dutlin.}$

Radcliffe, William. Beecb Court, Upper Deal, Kent.

Radford, C. A. Ralegh, F.S.A. Bradninch Manor, Devon.

Ramsay, A. B., M.A. Magdalene College, Cambridge.

Ramsay, Miss A. M., M.A. Lady Margaret Hall, Oxford.

L Ramsay, Sir W. M., D.C.L., Litt.D., LL.D., D.D., F.B.A. 17 Westcliff Road, Bournemouth.

L Randall, H. J., LL.B. Erw Graig, Bridgend, Glamorgan.

Randall-MacIver, D., M.A., D.Sc. 25 Corso d'Italia, Roma, Italy.

Rann-Kennedy, W. J, M.A. F.R.G.S. 6 Castle Hill Road, Dover, Kent.

Reade, W. H. V, M.A. Keble College, Oxford.

Reckitt, G. F. Io Downleaze, Sneyd Park, Bristol.

Record. S. P. M.A. Tanntm Schrol, Taunton.

Reed, A. E. Grammar Scbool, Brigg, Lincs.

Reed, Miss G. N. Giri's' Grammar Scbool, Watford.

Richards, Frank, M.A. 54 Mapperley Road, Nottingbam.

Richards, F. L, Assoc.M.Inst.C.E. Penryn, Kingsway, Woking, Surrey.

Richards, Rev. J. F. South Luffenbam Rectory, Stanford, Linis.

Richardson, Miss A. W. Westifield College, Hampstead, N.W.

Richardson, L. J. D., M.A. Fernshaw, Hilary Road, Llaniscben, Cardiff.

Richmond, Ian A., M.A. Buckley Hill House, Milnrow, Rochdale.

Richmond, J., B.A. 7633 Exposition Blud, Palmers Stn., Los Angeles, California.

Richmord, Prof. O. L, M.A. 5 Belford Place, Edinburgh.

Rickard, T. A. 250 Tunnel Road, Berkeley, California.

Roberts, Miss D. G., M.A. County Girls' School, Bishop Auckland, Durbam.

Roberts, J. Slingsby, 3 Powis Villas, Brighton.

Roberts, Miss M. D. Ingleburst, Huddersfield Road, Halifax, Yorks.

Roberts, Prof. W. Rhys, M.A., Litt.D. Tawranga, Peacehaven, Sussex.

Robertson, Prof. D. S, M.A. Trinity College, Cambridge.

Robertson, Prof. L. University of British Columbia, Vancouver, B.C.

Robinson, Prof. C. A., Jr. 63 Angell Street, Providence, R.I., U.S.A.

I Robinson, E. S. G., M.A. 23 Upper Phillimore Gardens, $W .{ }^{8}$

Rodd, The Rt. Hon. Sir Rennell, G.C.M.G.,G.C.V.O.,C.B. 25 Cavendish Square, $W^{\prime}$ :

Rosber, A. D. Eckington Villa, London Road, Reigate, Surrey.

Roos, Dr. A. G. 7 Waterloolaan, Groningen, Holland.

Rose, Prof. H. J., M.A. Edgecliff East, The Scores, St. Andrews, Fife.

Rossiter, Miss G. M, B.A. The High School, Beverley, Yorks.

Rothwell, Miss H. L. Moorelands, Malvern Wells.

Rouse, W. H. D., M.A., Litt.D. Histon Manor, Cambridge.

Rowland, L. G. Thwaitefield, Goathland, Yorks. 
xxiv

Rushforth, G. McN, M.A., F.S.A. Riddlesden, Malvern Wells.

Russell, Miss Agnes. Maltese Lodge, Chelmisford.

Ryott, H. A. Leathley, Nr. Otley, Yorks.

Salisbury, F. S., M.A. Dorset House, Asbford, Middlesex.

Salmon, E. T., B.A. Loughton Hlouse, Loughton, Essex.

Salt, Miss A. Star Croft, Licbfield, Staffs.

Sands, P. C., M.A. Pocklington School, East Yorks.

Saunders, G. F., M.A. clo Mrs. Kirby, Manor House, Redbridge, Soutbampton.

Sayce, Prof. A. H, D.Litt., Litt.D., LL.D., D.D. 8 Chalmers Crescent, Edinburgh.

L Scarth, Miss W. G. $97^{10}$ Cadogan Gardens, S.W. ${ }^{3}$

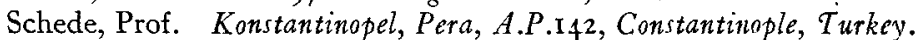

Scott, J. E, M.C., M.A. Gonville and Caius College, Cambridge.

Scullard, H. H. 52 Foscote Road, Hendon, N.W. ${ }^{4}$

Seltman, C. T., M.A., F.R.N.S. 39 Barton Road, Cambridge.

Semple, Prof. Patrick, M.A. Earlsfoot Terrace, University College, Dublin.

Seymour, P. A., M.A. Tesus College, Oxford.

Sharpe, Sir Montagu, K.C. D.L. Brent Lodge, Hanwell, $W$.

Shaw, Rev. J. Tunnicliffe. 47 Grange Avenue, Chapeltown Road, Leeds.

Shaw, R. C., F.R.C.S., L.R.C.P. I 68 Tulketh Road, Asbton, Preston, Lancs.

Sheepshanks, A. C. Eton College, Windsor.

Sheppard, J. T, M.A. Litt.D. King's College, Cambridge.

Sherman, Prof. C. P., D.C.L., LL.D. 3430 Tbirty-fourth Street, N.W., Wasbington, D.C., U.S.A.

Sherwin, G. A. Bramford, Cypress Road, Newport, I. of Wight.

Shields, Mrs. van Allen. 9 rue Spontini, Paris (xvi $)$, France.

Shove, Miss E. 330 Upper Ricbmond Road, Putney, S.W. ${ }^{15}$

Simpson, F. G., M.A., Hon.F.S.A. (Scot.). 45 Fern Avenue, Nerwcastle-on- $T_{y n e .}$

Sisson, M. A. Hucclecote, Near Gloucester.

Skeat, T. C. I7 Coombe Road, Croydon.

Sleeman, J. H, M.A. Malabide, Englefield Green, Surrey.

Sloane, Miss E. J. 8 University Road, Leicester.

Smith, A. H., C.B., F.S.A. 2 Balfour Road, Weybridge, Surrey.

Smith, G, M.A. Dulwich College, S.E. ${ }^{21}$

Smith, G. E. Lendrick Lodge, Stokes Hill. Waterlooville, Hants.

Snyder, Dr. G. A. S. Haringulietstraat 65, Amsterdam Zuid, Hollanl.

Souter, Prof. A., M.A., D.Litt., D.D., F.B.A. 9 College Bounds, Aberdeen.

Spiers, Henry, M.D., F.R.C.S.Ed. St. Dunstan's House, Melrose, Scotland.

Staines, E. A. Controller of Posts and Telegraphs, Selangor E' Pebang, G.P.O. KutllilLumpur, Fed. Malay States.

Standen, Miss E. A. clo Brown, Shipley $\sigma^{3}$ Co., 123 Pall Mall, S.W.1

Stannard, Harold, M.A. 55 Russell Square, W.C. ${ }^{1}$

Stevens, G. C., B.A. The School, Shrewsbury.

Stevens, C. E., B.A. 31 St. Aldate's, Oxford

Stevenson, G. H, M.A. University College, Oxford.

Stewart, Prof. H. The University, Leeds.

Stewart, Prof. J. A, LL.D. Christ Church, Oxford.

Stinton, T., M.A. The Higb School, Newcastle, Staffs.

Strangeways, L. R, M.A. The Grammar Scbool, Bury, Lancs.

L Streatfield, Mrs. 22 Park Street, Mayfair, $W .^{1}$

Strong, Mrs. S.Arthur, LL.D., Litt.D., F.S.A. 35 Via Balbo, Rome, Italy.

Strudwick, Miss Ethel, M.A. St. Paul's Girls' Scbool, Brook Green, Hammersmitb, $W .^{6}$

Sumner, Heywood. Cuckoo Hill, Soutb Gorley, Fordingbridge.

L Sutcliffe, Rev. E. F., S.J. Heythrop Hill, Chipping Norton, Oxon,

Swallow, Rev. Canon. Cbigwell Scbool, Essex.

Swinburne, Lady. Capbeaton, Newcastle-on-Tyne. 
Swithinbank, B. W., I.C.S. s/o Thomas Cook \& Son, Rangonn, Burma.

L Syme, Ronald, B.A. Trinity College, Oxford.

Symonds, Rev. H. H, M.A. Io Riversdale Road, Aigburth, Liverpsol.

Tandy, F. 75 Palace Road, Tulse Hill, S.W.z

Tarn, W. W. Muirtown, Nr. Inverness.

Taylor, H. M. 67 Monk Road, Ward End, Birmingham.

Taylor, J. E, M.A., B.Litt. Tonbridge Scbool, Tonbridge.

Taylor, Prof. I. R. Law Buildings, Bryn Mawr College, Pa., U.S.A.

Taylor, Miss M. V., M.A., F.S.A. 45 Woodstock Road, Oxford.

Taylor, W. G. 34 High Oaks Road, Welwyn Garden City, Herts.

Thompson, J., M.A. 28, St. Ledgers Road, Bournemouth.

L Tod, Marcus N, M.A. Oriel College, Oxford.

Towers, R. M, M.A. The College, Cheltenham.

Toynbee, Prof. Arnold J, M.A 3 Melina Place, St. Fobn's Wood, N.W. ${ }^{8}$

Toynbee, Miss Jocelyn, M.A. Newnbam College, Cambridge.

Turnbull, G. L, M.A. The Academy, Dingwall.

L Turner, Prof. C. H, D.Litt. F.B.A. Magdalen College, Oxford.

Urquhart, F. F, M.A. Balliol College, Oxford.

Van Buren, Prof. A. W. American Academy, Porta S. Pancrazio, Rome, Italy.

Van Essen, C. C. Museum, Carnegie Lane, Hague, Holland.

Vaughan, W. W, M.A. The Lodge, Rugby Scbool, Rugby.

Wackernagel, Prof. J. 93 Gartenstrasse, Basle, Switzerland.

Walker, Rev. F. G. The Rectory, Upten Lovel, Wilts.

Walker, R. H. Hillbrow 4, Rugby.

Walker, W. G, M.A. Crosby House, Oundle, Peterborough.

Walker, W. W, M.A. Io Queen Anne Terrace, Cambridge.

Wallace, W. Reeve. 4 Waverton Street, $W .1$

Wallis, Mrs. A. Morland, Darlington.

Wallis, D. E., B.A. 25 Sutherland Road, West Ealing, $W .{ }^{13}$

Walters, H. B, O.B.E., M.A., F.S.A. Britisb Museum, W.C. ${ }^{1}$

Ward, W. W. Merchants' Hall, Bristoi.

Warren, Miss. 5I Morwen Avenue, Mansfield Woudbouse, Notts.

L Watson, Rev. Prof. E. W, D.D. Christ Church, Oxford.

Watson, J. M. H. Fort-les-Bains, Amélie-les-Bains, Pyrénées Orientales, France.

Watson, W. Crum. Nortbfield, Balerno, Midlotbian.

Weavers, Miss E. M, B.A. 2 Goodwoyn Avenue, Mill Hill, N.W. ${ }^{7}$

Webb, Prof. Clement C. J., M.A., F.B.A. Walnut Tree House, Marston, Nr. Oxford.

Weber, F. Parkes, M.D. F.S.A. I 3 Harley Street, $W .^{1}$

Webster, Miss M. G. Alexandra College, Westcliff-on-Sea.

Wedd, N, M.A. King's College, Cambridge.

Weddell, A. W. Virginia House, Windsor Farme, Ricbmond, Virginia, U.S.A.

Weeck, W. N., M.A. Greenfields, The Park, Cheltenham.

Weekes, C. A. 3i Cannon Hill, London, N.W. ${ }^{6}$

L Westland, F. C., Lt.-Col. R.E. c/o Lloyds Bank, Cox's and King's Branch, 6 Pall Mall, S.W. ${ }^{1}$

Whatley, N, M.A. Clifton College, Bristoi.

Wheeler, R. E. Mortimer, D.Litt., F.S.A. London Museum, Lancaster House, St. Fames's, S.W. ${ }^{1}$

White, John G. Williamson Building, Cleveland, Obic.

Whitehead, G. O. 26 Pelbam Crescent, S.W. ${ }^{2}$

Whiteley, S. University College, Colombo, Ceylon.

Whitney, Rev. Prof. J. P, D.D. Emmanuel College, Cambridge.

Wilde, Mrs. II Stanley Crescent, $W .11$

Wilkinson, M. Bow, Durb:am. 
xxvi

L Willans, J. B. Dolforgan, Kerry, Montgomerysbire.

Williams, Miss G. H. The College, Pontypool, Mon.

L Williams, R, M.C. M.A. The Grammar School, Cozobridge, Glam.

Williams, Rev. W. Coleman. Caerwent Vicarage, Caerwent, nr. Chepstow.

Williams, Walter N, M.A., LL.B. Selwyn College, Cambridge.

Williamson, Prof. H., M.A. 34 Soutbway, N.W. ${ }^{11}$

Wilson, Mrs. G. M. Risebolme, Lincoln.

Wilson, Major H. C. B. Crofton Hall, Crofton, Wakefield.

Winbolt, S. E., M.A. Aclea, Worthing Road, Horsham.

Wood, H. McKinnon, B.A.

L Wood, J. C, B.A. 4 Carlisle Place, Bradford.

Woodard, E. A. T The Caffinites, Durbam School, Durbam.

Woodward, Miss A., M.A. Royal Holloway College, Englefield Green, Surney.

Woodward, A. M, M.A. The British Scbool, Athens.

Woodward, W. H, M.A. 39 Harley House, N.W. ${ }^{1}$

Woolley, C. L., M.A.

Woolley, Ernest, F.S.A. Collingriorth, Lemsford Road. St. Albans.

L Worley, Miss M. I., M.A. Quarry Field Cottage, London Road, Headington, Oxford.

Wright, W. E. I4 Wilbury Road, Hove, Sussex.

Wynne-Jones, Mrs. C. Thombill, Stalbridge, Dorset.

Yapp, Miss M. G. The Friends' School, Saffron Walden, Essex.

Yorath, Miss E. L. 9 Elliston Terrace, Carmarthen, S. Wales.

L Young, Miss A. M. Blackbeath High School, Wemyss Rond, Blackheath.

Young, G. M. All Souls College, Oxford.

Young, K. D, F.R.I.B.A. 17 Southampton Street, W.C.1

\section{STUDENT-ASSOCIATES.}

Alcock, Philip. Emmanuel College, Cambridge.

Allan, D. J. Christ Church, Oxford.

Barnes, M. A. Newnham College, Cambridge.

Behrens, W. E. B. Christ Church, Oxford.

Granville, B. New College, Oxford.

Hearnshaw, L. S. Christ Church, Oxford.

Helmore, J. R. C. New College, Oxford.

Hollis, H. N. Trinity College, Oxford.

Lake, Phyllis. Newnham College, Cambridge.

Long, R. S. St. John's College, Cambridge.

Lucas, Diana. 5o Oakley Street, Chelsea, S.W.

McCormick, P. 339 Main Street, Rutherglen, Glasgow.

Page, D. L. Christ Church, Oxford.

Pearson, L. I. C. Trinity College, Oxford.

Sparrow, John. New College, Oxford.

Stevens, P. T. New College, Oxford.

Sorroff, L. E. F. King's College Hostel, Vincent Square, London, S.W. ${ }^{1}$

Winnifrith, A. J. D. Christ Church, Oxford.

\section{LIBRARIES SUPPLIED UNDER COPYRIGHT ACT:}

CAḾrRidge: The University Library.

Oxford: The Bodleian Library.

Dublin : The Library of Trinity College.

EDinburgh : The Advocates' Library.

AberYstwyth : The National Library of Wales.

London: The British Museum, Copyright Office, W.C. ${ }^{1}$ 


\section{SUBSCRIBING LIBRARIES AND INSTITUTIONS.}

\section{GREAT BRITAIN AND IRELAND.}

Aberdeen : The Library of the University, Aberdeen.

Aberystwyth : The Library of the Univers.ty College of Wales, Aberystwyth.

Aldenham: The Library of Aldenham School, Elstree, Herts.

Ampleforth : The Library of Ampleforth Abbey, rork.

Bancor: The Library of University College of North Wales, Bangor.

BELFAST: The Library of the Queen's University, Belfast.

Birmingham: The Birmingham Archaeological Society, Birmingham.

Birmingham: The Central Free Library, Birmingbam.

Birmingham: The University Library, Birmingham.

Bradford: The Central Library, Bradford.

Brighton: The Public Library, Brighton.

Bristol: The Library of the University, Bristol.

Cambridge : The Library of Emmanuel College, Cambridge.

Cambridge : The Library of King's College, Cambridge.

Cambridge : The Library of Newnham College, Cambridge.

Cambridge : The Library of St. John's College, Cambridge.

Cambridge : The Museum of Classical Archaeology, Cambridge.

Cambridge : Trinity College Library, Cambridge.

CardifF: The Central Library, Cardiff.

CARdifF : The National Museum of Wales, Cardiff.

CARDIfF: The University College of South Wales, Cardiff.

Charterhouse: The Library of Charterhouse School, Godalming.

Chertenham: 'The Library of the Ladies' College, Cheltenbam.

Cifester: Chester and N. Wales Archaeological Society, Chester.

Colchester: The Libiary of the Corporation Museum, Colchester.

Derky: The Public Library, Derby.

Durlin: The King's Inns Library, Dublin.

Lublin : The National Library of Ireland, Dublin.

Dunder : The Albert Institute and Victoria Galleries, Dundee.

Dunder: The Library of University College, Dundee.

Durham: The Library of the University, Durbam.

Edinburgh : The Public Library, Edinburgh.

Edinburgh : The Royal Scottish Museum, Edinburgh.

EDInBurgh : The Signet Library, Edinburgh.

Edingurgh : The Library of the University, Edinburgh.

Englefirdd Green, Surrey: The Royal Holloway College, Englefield Green.

ETon : The Library of Eton College, $W$ indsor.

GalwaY: The Library, University Colleg, Galway.

Grascow: The Library of Baillie's Institution, Glasgorw.

Glascow: The Mitchell Library, Glasgow.

Grascow: The Library of the University, Glasgow.

Gloucester: The Bristol and Gloucestershire Archaeological Society, The Public Library, Gloucester.

Hawarden : St. Deiniol's Library, Hawarden.

Huddersfield : The Public Library, Huddersfield.

Huld : The Central Public Library, $H$ ull.

Hult : The Municipal Museum, Hull.

Huld: University College Library, Hull.

LeEDS: The Library, Commercial Street, Leeds.

LEEDS: The Library of the University, Leeds.

Letcester : The Library of Wyggeston Boys' School, Leicester. 
xxviii

Liverpoor: The Library of the University, Liverpool.

Liverpool: The Public Library, William Brown Street, Liverpool.

London: The Library of the Athenaeum Club, London.

London: The Department of British and Medieval Antiquities, British Museum, London.

London: The Department of Greek and Roman Antiquities, British Museum, Lınaon.

London: The Library of the Burlington Fine Arts Club, L'ndon.

London: The Guildhall Library, London.

London: The Library of King's College, London.

London: The London Library, St. James's Square, London.

London: The Library of Merchant Taylors' School, S.E. ${ }^{1}$

London: The Library of the Oxford and Cambridge Club, London.

London: The Library of the Reform Club, London.

London: The Library of the Royal Anthropological Institute, London.

London: The Library of the Royal Geographical Society, London.

London: The Library of the Royal Institution, London.

London: The Library of the Royal Institut: of British Architects, London.

London: The Library of Sion College, London.

London: The Library of the Victoria and Albert Museum, London.

London : Westfield College, Hampstead, London, N.W. ${ }^{3}$

London : The Library of the City of Westminster, London, S.W. ${ }^{1}$

London: The Library of Westminster School, London.

London: Dr. Williams's Library, London.

MaLvern : The Grundy Library, Malvern College, Malvern.

Manchester: The Library of the Grammar School, Manchester.

Manchester : The John Rylands Library, Manchester.

MANCHester: The Library of the Victoria University, Manchester.

Newcastle-Upon-Tyne: The Library of Armstrong College, Newcastle-upon-Tyne.

Newcastle-Upon-'Tyne: The Iiterary and Philosophical Society, Newcastle-upan-. Tyne.

Newcastre-upon-Tyne: The Public Library, Newcastle-upon-Tyne.

Nottingham : The Library of University College, Nottingham.

Ounder: The Library of Oundle School, Oundle.

Oxford: The Library of All Souls College, Oxford.

Oxford: The Library of the Ashmolean Museum, Oxford.

Oxford: The Library of Balliol College, Oxford.

Oxford: The Library of Brasenose College, Oxford.

Oxford: The Library of Christ Church, Oxford.

Oxford: The Senior Library, Corpus Christi College, Oxford

Oxford: The Library of Exeter College, Oxford.

OXFORD : The Library of Hertford College, Oxford.

OxFord: The Library of Jesus College, Oxford.

OXFord: The Library of Keble College, Oxford.

OXFORD: The Library of Magdalen College, Oxford.

OXford: The Library of Manchester College, Oxford

Oxford: The Library of Merton College, Oxford.

OxFord: The Library of New Colleg2, Oxford.

Oxford: The Library of O.iel College, Oxford.

Oxford: The Library of Somerville College, Oxford.

Oxford: The Library of St. John's College, Oxford.

Oxford : The Library of Trinity College, Oxford.

Oxfop.d: The Library of University College, Oxford.

Oxford: The Library of the Union Society, Oxford.

Plymoutu: The Free Public Library, Plymouth.

REAding: The Library of the University, Reading.

Rugby : The Arnold Library, Rugby School, Rugby.

St. Andrews: The Library of the University, St. Andrews. 
Shefrield: The Free Public Library, Sheffield.

Shefrield : The Library of the University, Sheffield.

Southampton: Ordnance Survey, Soutbampton.

Southampton: University College Library, Soutkampton.

Southend-on-Sea : The Central Public Library, Soutbend-on-Sea.

Streatham Hild: The Library of the Streatham Hill High School, Streatham Hill.

Swansea : The Library of University College, Swansea.

UpPingham: The Library of Uppingham School, Uppingham.

Wantage: St. Mary's School, Wantage, Berks.

Windsor: The Library of Beaumont College, Old Windsor.

York: The Yorkshire Philosophical Society, The Museum, York.

York: The Yorkshire Museum, York.

\section{BRITISH DOMINIONS.}

Adelaide, S. Australia: The Public Library, Adelaide.

Adelaide, S. Australia: The Library of the University, Adelaide.

Brisbane, Queensland : The Library of the University of Queensland, Brisbane.

Cape Town, S. Africa: The South African Public Library, Cape Town.

Christchurch, New Zealand: The Library of Canterbury College, Cbristcburch.

Содомво : University College, Colombe, Ceylon.

Dunedin, New Zealand : The Library of Otago University, Dunedin.

Grahamstown, S. Africa : The Library of Rhodes University College, Grabamstown

Hobart, Tasmania : The University of Tasmania.

Kingston, Ontario: The Library of Queen's University, Kingston.

London, Ontario: The Western University Library, London.

Melbourne, Australia: The Public Library, Melbourne.

Melbourne, Australia: The Library of the University, Melbourne.

Montreal, Canada: The Library of the McGill University, Montreal.

Point Grey, British Columbia: The University Library, Point Grey.

Pretoria, Transvaal, S. Africa: The T.U.C. Co-operative Supply Association Ltd., Transvaal University College, Pretoria.

Stellen bosch, S. Africa : The University of Stellenb : sch, Stellenboseb.

Sydney, New South Wales: The Public Library, Sydney.

Sydney, New South Wales: The University Library, Sydney.

Toronto, Canada: The University Library, Toronto.

Vancouver, British Columbia: The University Library, Point Grey, Vancouver.

\section{THE UNITED STATES OF AMERICA.}

Amherst, Mass: The Library of Amherst College, Amberst.

Andover, Mass : The Library of Phillips Academy, Brechin Hall, Andover

Ann Arbor, Michigan: The Library of Michigan University, Ann Arbor.

Athens: Carnegie Library, Ohio University, Atbens.

Aurora, New Yorr : The Library of Wells College, Aurora.

Austin, Texas: The Library of Texas University, Austin.

Baltimore, Maryland : The Library of Johns Hopkins University, Baltimore.

Berkeley, California: The Library of the University of California, Berkeley.

Bethlehem : Lehigh University Library, Betblehem, Pa.

Bloomington, Ind.: Indiana University Library, Bloomington.

Boston, Mass : The Library of the Athenaeum, Boston.

Boston, Mass: The Library of the Museum of Fine Arts, Boston

Boston, Mass.: The Public Library, Boston.

Brooklyn, New York : The Museum, Brooklyn Institute of Arts and Sciences, Brooklyn.

Brunswick, Maine: The Library of Bowdoin College, Brunswick.

Bryn Mawr, PA.: The Library of Bryn Mawr College, Bryn Mawr.

Burlington: The University of Vermont, Burlington.

Cambridge, Mass. : The Library of Harvard University, Cambridge.

Chapel Hill, N. Carolina : The Library of the University of N. Carolina, Chapel Hill. 
Charlottesvilde, $\mathrm{V}_{\mathrm{A}}$ : The Library of the University of Virginia, Charlottesville.

Chicago, Ill. : Loyola University Library, Cbicago.

Chicago, Ill.: The Newberry Library, Chicago.

Chicago, Ill: The Library of the University, Cbicago.

Cincinnatr, Oho: The Library of the University, Cincinnati.

Cleverand, Ohio: The Library of Adelbert College, Cleveland

Cleveland, Ohro: The Public Library, Cleveland.

Cuinton, New York: The Library of Hamilton College, Clinton.

Columbus, Ohro: The State University, Obio.

Durham, N.C.: The Library of Duke University, Durbam, N.C.

Easton, $\mathrm{PA}_{\mathrm{A}}$ : The Library of Lafayette College, Easton.

Evanston, Ill : The Library of the North Western University, Evanston.

Grinnell, Iowa: The Library of Grinell College, lowa.

Haverford: Haverford College Library, Haverford, Pennsylvania.

Indianapolis, IND. : Butler College Libriry, Indianapolis.

Iowa Ciry : The Library of the State University, Iowa.

Ithaca, New York: The Library of Cornell University, Itbaca.

LaWrence, Kansas : The Library of Kansas University, Iawrence

Los Angeles, California: The Library of California University, Los Angeles.

Madison, Wisconsin : The Library of the University of Wisconsin, Madison.

Middletown, Conn.: The Library of the Wesleyan University, Middletown.

Minneapolis, Mrnn.: The Library of the University of Minnesota, Minneapolis.

New Haven, Conn.: The Library of Yale Universitv, New Haven.

New York: The American Geographical Society, I56th Street, Broadway, New rork.

New York: The Library of Columbia University, New York.

New York: The Metropolitan Museum of Art, New York.

New York: The Public Library, New York.

New York : The University Library, University Heights, New rork.

Norman, Orlanoma: The Library of Oklahoma University, Norman.

Northampton, Mass : The Library of Smith College, Northampton.

Oberdin : Obarlin College, Oberlin.

Oнно : Cleveland Pablic Library, Obio.

Philadelphia, Pa.: The Free Library, Philadelpbia.

Philadelphia, Pa.: The Library Company, Philadelpbia.

Philadelphia, Pa. : The Library of the University of Pennsylvania, Pbiladelphia.

Philadelphia, PA.: The Library of the University Museum, Pbiladelphia.

Pitrsburg, Pa.: The Carnegie Library, Pittsburg.

Pougn KeE Psie, New York: The Library of Vassar College, Poughkeepsie.

Princeto.v, New Jersey: The University Library, Princeton.

Providence, Rhode Island : The Library of Brown University, Providence.

Rochester, N.Y.: The Library of Rochester Univarsity, Rochester.

Sr. Lours, MrssourI : The Library of Washington University, St. Louis.

Schenectady, New York : Union College Library, Schenectady.

Seattle : University of Washington Library, Seattle, Wasbington.

South Hadeey, Mass : The Library of Mount Holyoke College, South Hadiey.

Stanford, California : The Library of the University, Stanford.

Swarthmore, $\mathrm{P}_{\mathrm{A}}$ : The Library of Swarthmore College, Swarthmore.

Terre Haute, Ind : The Library of Indiana State Normal School, Terre Hante.

URBana, ILL: The Library of the University of Illinois, Urbana.

Washington: The Library of the Catholic University of America, Washington, D.C.

Washington: The Library of Congress, Wasbington.

Wellesley, MAss : The I,ibrary of Wellesley College, Wellesley.

\section{AUSTRIA.}

Graz : Archäologish-epigraphisches Seninar der Universitüt, Graz.

VIenNa : Archänlogi ch-epigraphisches Seminar der Universität, Vienna. 


\section{BELGIUM.}

Brussels: Musées Royaux du Cinquantenaire, Brussels.

Brussels : La Société des Bollandistes, Brussels.

Liége: The Faculty of Philosophy and Letters at the University, Liege

BULGARIA.

SofiA : I'Institut archéologique Bulgare, Rakowska 127, Sofia.

\section{CHINA:}

Périvg: Metropolitan Library, Peking.

\section{CZECHOSLOVAKIA.}

Prague: The Public University Library, Prague.

\section{DENMARK.}

Copenhagen: Kongelike Bibliothek, Copenbagen.

Copenhaczn: Ny Carlsberg Glyptotek, Copenhagen.

EGYP'T.

Alexandria : La Musée Greco-Romain, Alexandria.

Cairo: La Bibliothèque de l'Université égyptienne, Abassieh, Catro.

\section{ESTONIA.}

Tartu (Dorpat) : Institute of Classical Archaeology, The University, Tartu-

\section{FRANCE.}

Algiers, N. Africa : La Bibliothèque de l'Université, Alget.

Grenoble : La Bibliothèque de l'Université, Grenoble, Isère.

Paris : La Bibliothèque de l'Universitć à la Sorbonne, Paris.

Paris: La Bibliothèque de l'Ecole Normale Superieure, Parts.

Paris : I.a Bibliothèque Nationale, Paris.

Paris: I a Bibliothèque de l'Institut de France, Paris.

Paris : La Bibliothèque d'Art et d'Archéologie, Paris.

Strasboctro: Bibliothèque nationale et universitaire, Strasbourg.

\section{GERMANY}

BerLin : Arch. Scminar d. Universität, Berlin.

Berliv : Institut für Altertumskunde, Berlin.

BerLin : Universitätsbibliothck, Beriin.

Berlix: Preussische Staatsbibliothek, Berlin.

BresLaU : Universiiätsbibliothek, Breslau.

Fran KFURt a/M : Stadtbibliothek, Frankfurt a $M$.

Freiberg-i-Breisgau : Universitätsbibliothek, Freiburg-i-Breisgau.

GIESSEN : Universitätsbibliothek, Giessen.

Görtingen: Uaiversitätsbibliothek, Göttingen.

Greifswald : Lniversitätsbibliothek, Greifswald.

Hamburg : Stadt-u. Universitätsbibliothek, Hamburg.

Heidecberg: Universitätsbibliothek, Heidelberg.

Kiet: Universitätsbibliothek, Kiel.

Koein-Bayentual : Arch. Institut d. Universität, Koeln-Bayenthal.

Koflx-Rhen : Universitat-u.-Stadtbibliothek, Koeln-Rhein.

KöN IGSBERG : Universitätsbibliothek, Königsberg.

LeIPZIG : Arch. Institut d. Universität, Leipzig.

LeıPzig : Universitätsbibliothek, Leipzig.

Marburg : Universitätsbibliothek, Marburg. 
xxxii

Municu : Bayr. Staatsbibliothek, Munich.

Munich : Universitätsbibliothek, M Iunich.

Münster: Universitätsbibliothek, Münster.

Rosтоск : Universitätsbibliothek, Rostock.

Trier : Provinzialmuseum, Trier.

Tübivgen: Archäologisches Institut der Universität, Tülingen.

Tốrлgen: Universitätsbibliothek, Tühingen.

Würzburg: Kunstgeschichtliches Mussum der K. Julius-Maximilians Universität, W'ür $\approx$ burg.

WürzbuRG : Universitätsbibliothek, Wïrzburg.

GREECE.

Athens : American School of Classical Studies, Athens.

Arhens: Deutsches archaeologisches Institut, Phidias-str. I, Athens.

\section{HOLLAND.}

The Hague: Koninklijke Bibliotheek, The Hague.

Leeuwarden : Buma Bibliotheek, Leeuzarden.

LEIDEN : Bibliothe $\mathrm{k}$ der Rijks-Universiteit, Leiden.

Nymegen : Rijks-Museum G. M. Kam, Nymegen.

UTRECHT: Bibliotheek der Universiteit, Utrecht.

\section{HUNGARY.}

Budapest : The Museum in Aquincum, Budapest.

Budapest: University Library, Budapest.

\section{ITALY}

Caglinri (Sardegna): Biblioteca della Facultà di Lettere e Filosclía, R. Università, Cagliari.

Florence: R. Biblioteca Nazionale Centrale, Florence.

Padua : Gabinetto d'Archeologia della R. Università, Padua.

Pavia: Biblioteca della Facultà di Filosofia e Lattere, R. Università, Pavia.

Rome: The American Academy in Rome, Porta S Pancrazio, Rome

Rosie: Deutsches Archäologisches Institut, Via Sardegna, 79, Rome (25).

Rome: Gabinetto Epigrafia, R. Università, Rome.

Rome: La Biblioteca Nazionale Vittorio Emanuele, Rome.

Rome: The Library of the British School, Valle Giulia. Rome.

Rome: Ufficio Scavi di Ostia, Rome.

Turin : La Biblioteca Nazionale, Turin.

JAPAN.

Tокуо: The Imperial University Library, Tokyo.

Osso : Universitetsbibliotek, Oslo.

NORWAY.

PALESTINE.

Jerusalem: The British School of Archaeology, Jerusalem.

POLAND.

CRacow: Archaeological Institute, 2 St. Anne Street, Cracoso.

\section{RUSSIA.}

Leningrad : Gosudarstrennoi Akademii Istorii Materialnoi Kultury, Cl. Chalturini 5. Leningrad.

LENINGRAD : The Hermitage Museum Library, Chalturinastr. 35, Leningrad.

Moscow: Historical State Museum, Moscow. 


\title{
SWEDEN.
}

Gothenburc: Stadbiblioteket, Göteborg.

LUnd: The Library of the University, Lund

Stoскноlm: The Royal Library, Stockbolm.

Uppsala: The Library of the University, Uppsala

SWITZERLAND.

Lausanne: M. Charles Favez, L'Association de Lectures philologiques, 39 Bvò. de Grancy, Lausanne.

Zürich : Zentralbibliothek, Zürich

\section{EXCHANGES OF PUBLICATIONS.}

The following is a list of Societies, Institutions, etc, with which exchanges of publications have been arranged:

\author{
FRANCE.
}

Paris : L'Association Guillaume Budé, 95, Boulevard Raspail, Parzs.

\section{GREAT BRITAIN.}

Carlisle: Cumberland and Westmorland Antiquarian and Archaeological Society, Tullie House, Carlisle.

Devizes: The Wiltshire Archaeological and Natural History Society, The Museum, Devizes.

Edinburgh : The Society of Antiquaries of Scotland, Queen Street, Edinburgh.

Holywell: The Cambrian Archaeological Association, Whitford, Holywell.

Leeds: The Yorkshire Archaeological Society, ro Park Place, Leeds.

Lewes : The Sussex Archaeological Society, Lewes.

London: The Society of Antiquaries, Burlington House, Piccadilly, London.

Newcastle-upon-Tyne: The Society of Antiquaries, Newcastle-upon-Tyne.

\section{GERMANY.}

BerLin : Zeitschritt für Ethnologie.

BerLin : Bayerisch. Numismat. Gesellschaft, Karlstrasse Io, Munich.

Bonn: Provinzialmuseum, Bonn.

Bonn: Verein von Altertumsfreunden im Rheinlande, Bonn.

Frankfurt a. M: Deutsches Archäologisches Institut, strasse i2, Palmgarten, Frankfurt am $M$.

Marnz: Röm.-Germanisch. Centralmuseum, Mainz.

Munich : Archäologisches-Seminar der Universität, Munich.

HUNGARY.

Budapest: Magyar Nemzeti Museum.

ITALY.

Milan : Historia, Via Moscova, 17, Milan.

Rome: Accademia di Romania, Via Emilio di Cavaliere, Rome (36).

Rome: L'École française de Rome.

Rome: Pontificio Istituto Biblico, Piazza della Pilotta 35, Rome.

Roma : Rivista di Archeologia Cristiana, Via Napoleone III ${ }^{1}$, Rome.

Roma : Rivista di Archeologia e Storia dell'Arte. Palazzo Venezia, 3, Rome.

Turin : Rivista di Filologia e d'Istruzione Classica (Casa Editrice Giovanni Chiantore,

Via Vittorio Amedeo ii, 18, Turin. ${ }^{3}$ )

$$
\text { ROUMANIA. }
$$

BUCHAREST: The Academia Română.

SPAIN.

Barcelona: Institut d'Estudis Catalans, Palau de la Diputació, Barcelona. 